INTERDISCIPLINARIA ARCHAEOLOGICA

\title{
West Pontic Diets: A Scientific Framework for Understanding the Durankulak and Varna I Cemeteries, Bulgaria
}

\author{
Noah V. Honch ${ }^{\mathrm{a}}$, Tom Higham ${ }^{\mathrm{a}}$, John C. Chapman ${ }^{\mathrm{b}}$, Bisserka Gaydarska ${ }^{\mathrm{b}}$, Henrieta Todorova ${ }^{\mathrm{c}}$, \\ Vladimir Slavchev ${ }^{\mathrm{d}}$, Yordan Yordanov ${ }^{\mathrm{e}}$, Branimira Dimitrova ${ }^{\mathrm{e}}$ \\ ${ }^{a}$ Research Laboratory for Archaeology and the History of Art, University of Oxford, Dyson Perrins Building, South Parks Road, Oxford OX1 3QY, UK \\ ${ }^{b}$ Department of Archaeology, Durham University, Durham DH1 3LE, UK \\ ${ }^{c}$ Bulgarian Academy of Sciences, 5 Noemvri Str., 1040 - Sofia, Bulgaria \\ ${ }^{d}$ Regional Museum of History, 41 Maria Louiza Blvd., 9000 Varna, Bulgaria \\ eInstitute for Experimental Morphology and Anthropology, Bulgarian Academy of Sciences, 1113 - Sofia, Tsarigradsko shoes blvd. 73 , Bulgaria
}

\section{ARTICLE INFO}

\section{Article history:}

Received: 1. July 2013

Accepted: 16. December 2013

\section{Key words}

stable isotope analyses

AMS dating

reservoir effect

Varna I

Durankulak

Bulgaria

dietary signatures

Chalcolithic/Aeneolithic

\begin{abstract}
$A B S T R A C T$
Stable isotope analysis and AMS dating of human and animal bone from the Bulgarian Black Sea coastal sites of Varna I and Durankulak provide fascinating insights into their spatial development as Neolithic and Aeneolithic (Copper Age/Chalcolithic) cemeteries, their associated chronologies, and the dietary signatures of the individuals buried there. The question of the Black Sea reservoir effect is explored, together with a comparison of dietary signatures with other European populations. The isotopic results suggest the populations of Varna and Durankulak primarily utilised C3, terrestrial-based protein sources, despite their presumed proximity to the Black Sea. No significant correlation was found between the isotopic signatures and the material wealth of individuals at Varna, which may have implications for theories regarding emergent social/economic hierarchies in prehistory. The AMS results suggest the Varna I cemetery was utilised for a short period of 70-155 years $( \pm 1 \sigma)$ in the middle of the fifth millennium BC. Although only a small proportion of the Durankulak burials was dated, evidence suggests the cemetery was in use for at least half a millennium and burials had likely ceased by $4450 \mathrm{BC}$, in the early part of the Late Aeneolithic, at approximately the same time as those at Varna I. The implications of the AMS dates are discussed in relation to the development of a Black Sea innovation centre in ceramics and metallurgy and the diffusion of these innovations to other parts of the Balkans and the north Pontic zone. Critical issues are identified for Early and Middle Aeneolithic chronology with respect to the dating sequence of the Durankulak cemetery.
\end{abstract}

\section{Introduction}

The discovery of the Varna I cemetery over forty years ago unveiled the world's oldest assemblage of goldwork, the sheer quantity and elegance of which rivalled prominent but much later finds in Mesopotamia and Egypt (Ivanov 1975; Chapman 1990; Renfrew 1978; 1986). Varna has widely been interpreted as proof of social complexity (Renfrew 1986), statehood (Raduntcheva 1989), and the existence of widespread inter-regional exchange networks in the East Balkans (Todorova 1995). To some, Varna has even been the focus of discourse related to the birth of European Civilization

*Corresponding author. E-mail: j.c.chapman@durham.ac.uk (e.g. Ivanov 2000). Whether or not this connection is tenable, the wealth and diversity of material culture at Varna suggests it was a symbolic focus for the cultural achievements of the Aeneolithic Period (Chalcolithic or Copper Age) in the Eastern Balkans (Figure 1).

Unlike most Aeneolithic cemeteries in the East Balkans, Varna I is not affiliated with a settlement. Thirteen pile dwellings have been located near the Varna Lakes (Ivanov 2000), but their relevance to the cemetery is not firmly established ( $c f$. Slavchev 2010 with Chapman 2010). It is thus difficult to link the 300 or so Varna burials (Figure 2) to a domestic or economic context that may provide insight into the regional diets and subsistence strategies of humans in antiquity. The lack of comprehensive publications on the 


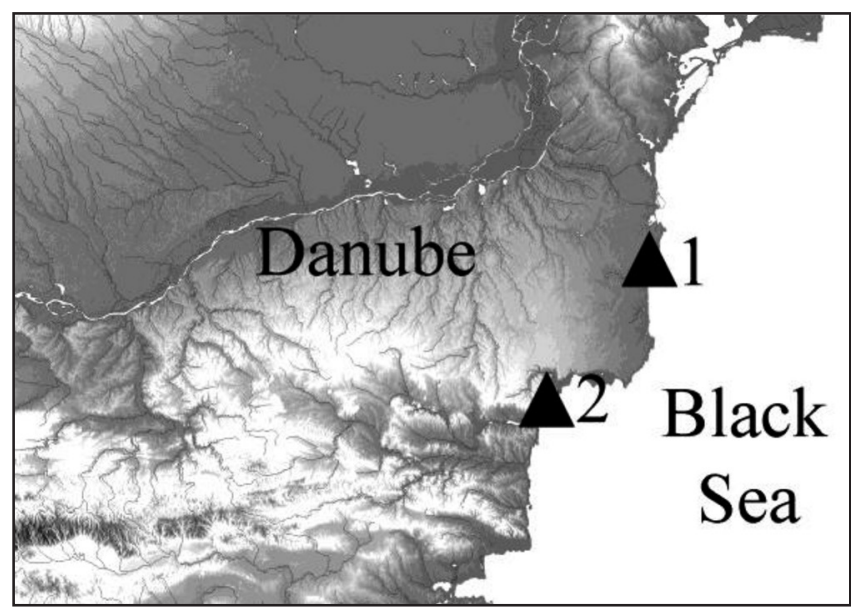

Figure 1. Location map of key sites: 1 - Durankulak; 2 - Varna.

cemetery and its excavations have also posed formidable barriers to systematic archaeological investigations (Chapman 2000, 174). Despite such analytical challenges, it is clear that the number and diversity of grave goods (e.g. pottery, Spondylus bangles, gold jewellery) varies substantially between the inhumations at the site (Honch et al, 2006). Inter-burial differences in mortuary goods have been interpreted as evidence for the emergence of social differentiation during the Aeneolithic (e.g. Renfrew 1978; 1986). If social differentiation existed, however, it remains unclear whether this differentiation was manifested in the diet (i.e. whether individuals had access to different foods on the basis of their social standing or role within the community).

The tell settlement of Durankulak is the only West Pontic site with extensive excavations of both Neolithic and Aeneolithic settlements (Todorova, Dimov 1989; Todorova 1983; 1986) and is associated with an impressive cemetery consisting of more than 1,200 Neolithic and Aeneolithic burials - one of the largest concentrations of prehistoric graves in the Balkans (Todorova 2002) (Figure 3). The tell is located on a large island in the western part of Lake Durankulak, a coastal lagoon with a continuous sediment history dating back to the Neolithic (Bozhilova, Tonkov 1985; 2002; Marinova 2003; Todorova 1989). The Aeneolithic phases of the settlement contain stonewalled architecture - a novel phenomenon in the region that is both a hallmark of the Middle to Late Hamangia culture and evidence of settlement differentiation (Todorova 1983; 1995; Chapman 1991; Boyadziev 2004). A group of 14 AMS dates from the Durankulak complex provides the basis for an absolute chronology of the cemetery.

It has long been recognised that there has been a clear shortage of scientific data on the humans buried at Varna and Durankulak. The aim of this paper is to confront that gap and use Stable Isotope Analysis (SIA) to reconstruct the diets and subsistence practices of the Varna and Durankulak humans and to investigate the potential relationship, if any, between the diet and status of the interred individuals both at the intra-site and the inter-cemetery levels. The two series of AMS dates for Varna and Durankulak provide an essential chronological framework for the discussion of the SIA results.

\section{Stable Isotope Analysis and Palaeodietary Recon- struction}

Stable isotope analysis (SIA) is a viable method of obtaining dietary information from the preserved biological remains of ancient humans (e.g. bones and teeth), and is particularly useful when associated archaeological information is limited. SIA functions on the premise that a relationship exists between the stable isotopic composition of the diet and consumer tissues. The isotopic composition of biological tissues is determined by the chemical composition of consumed foods and various isotopic fractionation events that occur during the synthesis and degradation of body tissues (Schwarcz, Schoeninger 1991). Most SIA investigations reconstruct human diets by examining two isotopic ratios $\left({ }^{13} \mathrm{C} /{ }^{12} \mathrm{C}\right.$ and $\left.{ }^{15} \mathrm{~N} /{ }^{14} \mathrm{~N}\right)$ in the bone and/or teeth collagen of ancient humans, and comparing them to the same ratios of contemporaneous fauna in order to situate the humans in the appropriate palaeo-ecological context. The technique is well established and is underpinned by a large body of controlled feeding experiments (Hare et al. 1991; Howland et al. 2003; Jim et al. 2006; McCullagh et al. 2008) and applied investigations involving modern (DeNiro, Epstein 1978; 1981; Schoeninger, DeNiro 1984) as well as ancient ecosystems (Chisholm et al. 1982; Iacumin et al. 2004; White et al. 2001; Yoneda et al. 2002).

\section{Methods and Materials}

\subsection{The Pre-Treatment and Analysis of Stable Isotope Samples}

Bone samples were shotblasted with aluminium oxide to remove soil detritus and 500 to $750 \mathrm{mg}$ of bone was removed and crushed. Crushed bone was demineralised in $0.5 \mathrm{M} \mathrm{HCl}$ for 48 hours at $<10{ }^{\circ} \mathrm{C}$, or until $\mathrm{CO}_{2}$ ceased to evolve. The samples were rinsed with deionised MilliQ water, placed in $\mathrm{pH} 3$ water and gelatinised on a hotplate at $75^{\circ} \mathrm{C}$ for at least 48 hours. The supernatant was decanted with an EziFilter ${ }^{\mathrm{TM}}$ and the soluble gelatine freeze-dried.

Bulk collagen from each sample was weighed in triplicate to between 2.0 and $3.5 \mathrm{mg}$ in tin capsules. Isotopic analyses were conducted using an automated carbon and nitrogen analyser and a continuous-flow isotope-ratio-monitoring mass spectrometer (cf-irm-ms; ANCA Roboprep coupled to a 20/20 mass spectrometer or a Carlo Erba carbon and nitrogen elemental analyser coupled to a Europa Geo 20/20 mass spectrometer). Conventional replicate measurement errors are typically $\pm 0.2 \%$ for $\delta^{13} \mathrm{C}$ and $\delta^{15} \mathrm{~N}$.

\subsection{Measures of Sample Integrity}

The integrity of SIA samples was based on a combination of $\mathrm{C}: \mathrm{N}$ ratios, collagen yield, and minimum weight yields of 


\section{.}

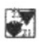

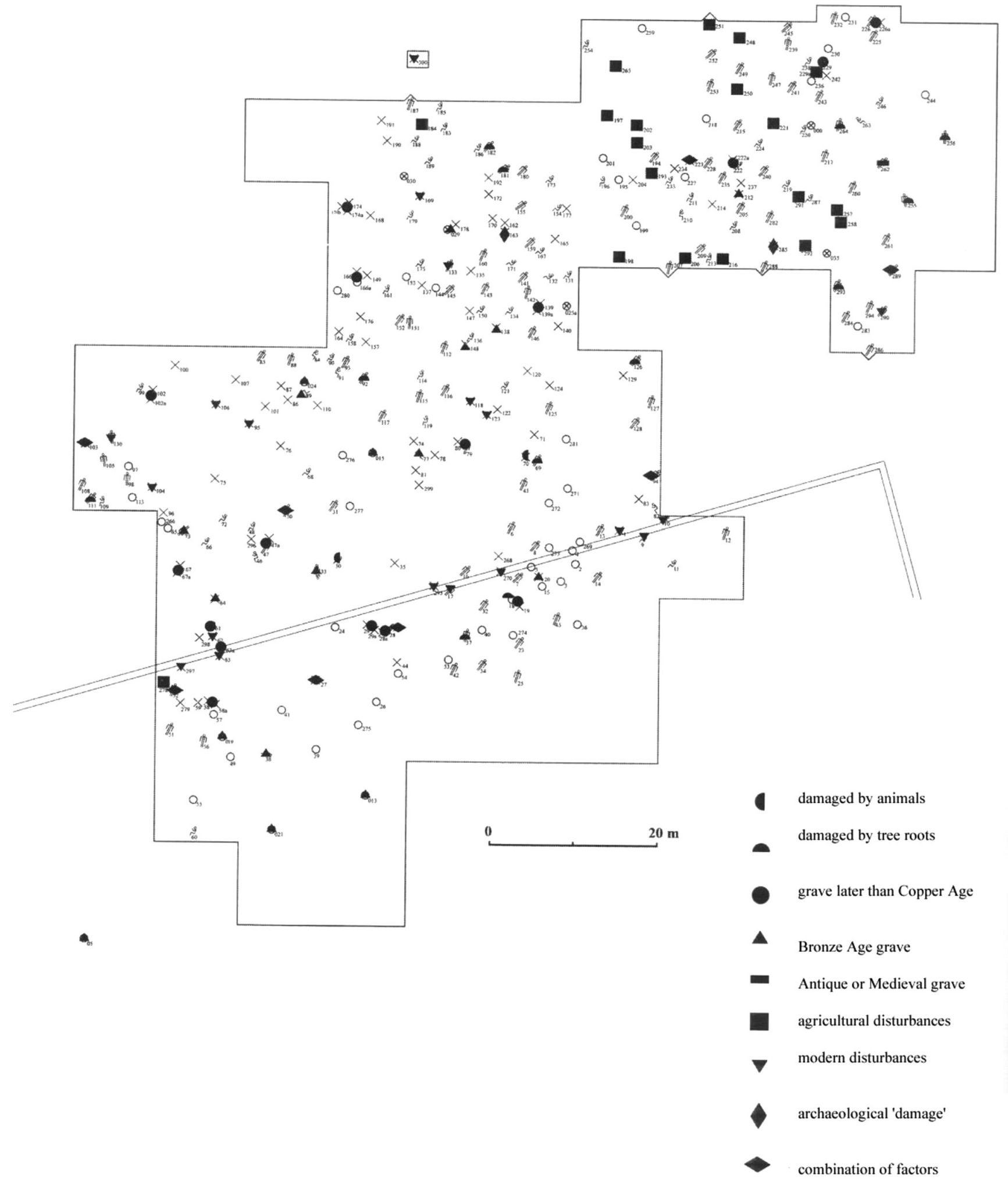

Figure 2. Plan of Varna cemetery (source: Vladimir Slavchev). 
carbon and nitrogen. Collagen with a $\mathrm{C}: \mathrm{N}$ ratio of 2.9-3.5 (akin to modern bone) was accepted to yield credible $\delta^{13} \mathrm{C}$ and $\delta^{15} \mathrm{~N}$ values (DeNiro 1985). Although a high collagen yield cannot ensure that bone protein is uncontaminated it can improve the chances of obtaining biogenic signals over bones with little collagen (van Klinken 1999). Samples were accepted here if they were $\geq 1 \%$ wt. $\%$ collagen. Minimum weight yields of $0.5 \mathrm{mg}$ for carbon and $0.2 \mathrm{mg}$ of nitrogen, per combusted collagen sub-sample $(2.0$ to $3.0 \mathrm{mg}$ total weight), were also used to ensure sample integrity.

Triplicate isotope values were averaged for SIA unless otherwise stated. Where a triplicate sample failed due to analytical machine failure or the tenets of sample integrity, duplicate measurements were averaged. Single measurements of small samples are reported in select cases, pending their acceptance against the other criteria discussed.

\section{Results and Discussion}

\subsection{AMS dates}

The programme of AMS dating at Oxford has produced consistent sets of results for the Varna cemetery (Higham et al. 2007; Chapman et al. 2006) and the Durankulak complex. The paired human - animal bone samples show that, in contrast to the results of Reimer and Reimer (2001) and Aksu et al. (2002), there is likely to be no, or at least a small, marine reservoir effect on the dates of these two coastal sites. In addition, the Durankulak and Varna collections provided the comparative animal isotope values that are so vital to palaeodietary studies. Samples were selected from all of the major excavation areas at Varna, including the materially rich 'core' area (Figure 2). In addition to considerations of burial context and bone preservation, AMS samples were selected

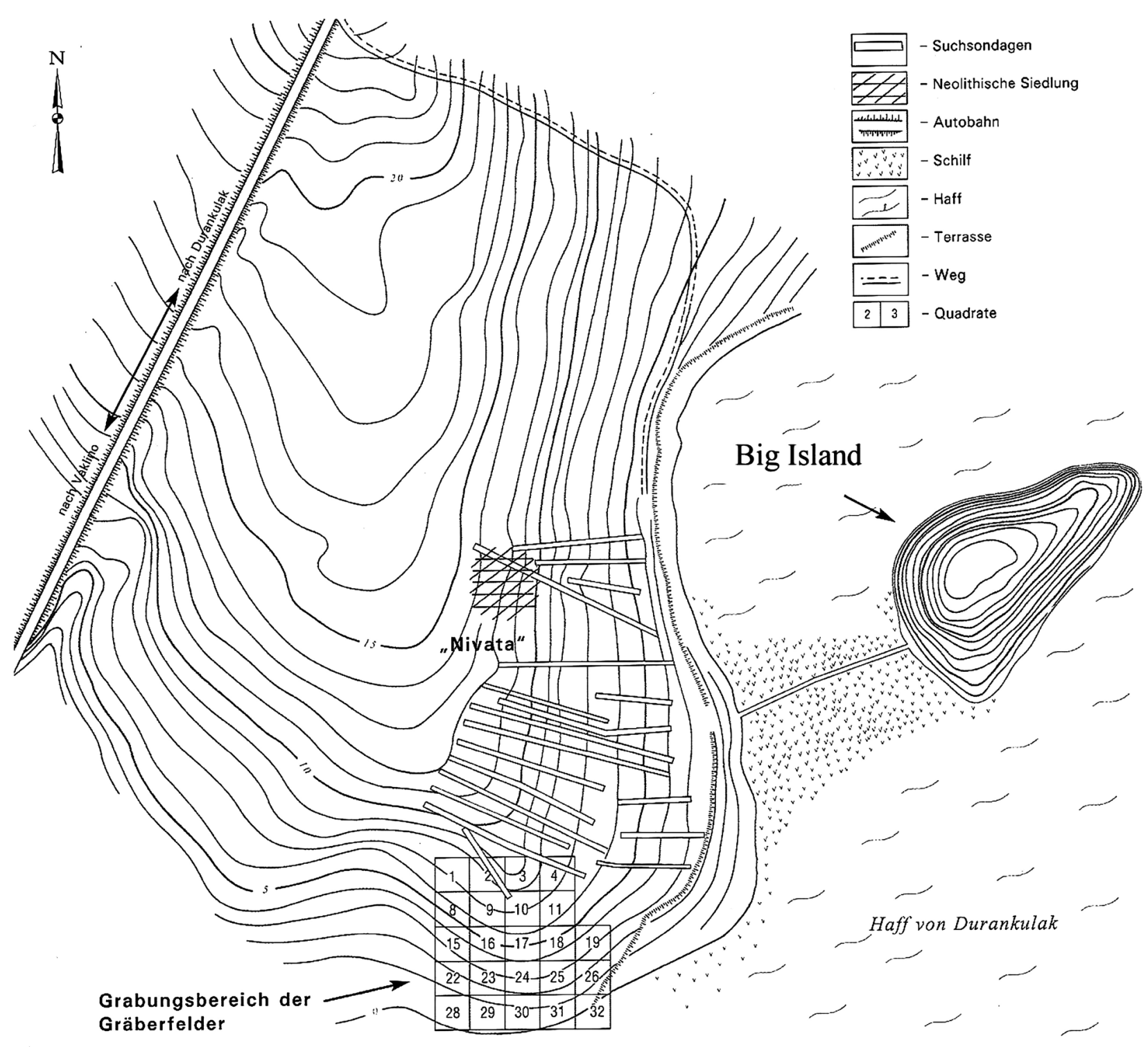

Figure 3. Plan of the Durankulak complex (source: Todorova 2002). 
Figure 4. Calibration model for the Varna I cemetery human bone AMS determinations. The likelihoods are modelled as a single phase of activity. The agreement index $(84.5 \%)$ indicates that there is acceptable agreement for every determination within the archaeological constraints imposed on the dates, with the exception of OxA-13865 OxA-13811 is not included due to low wt \% collagen.

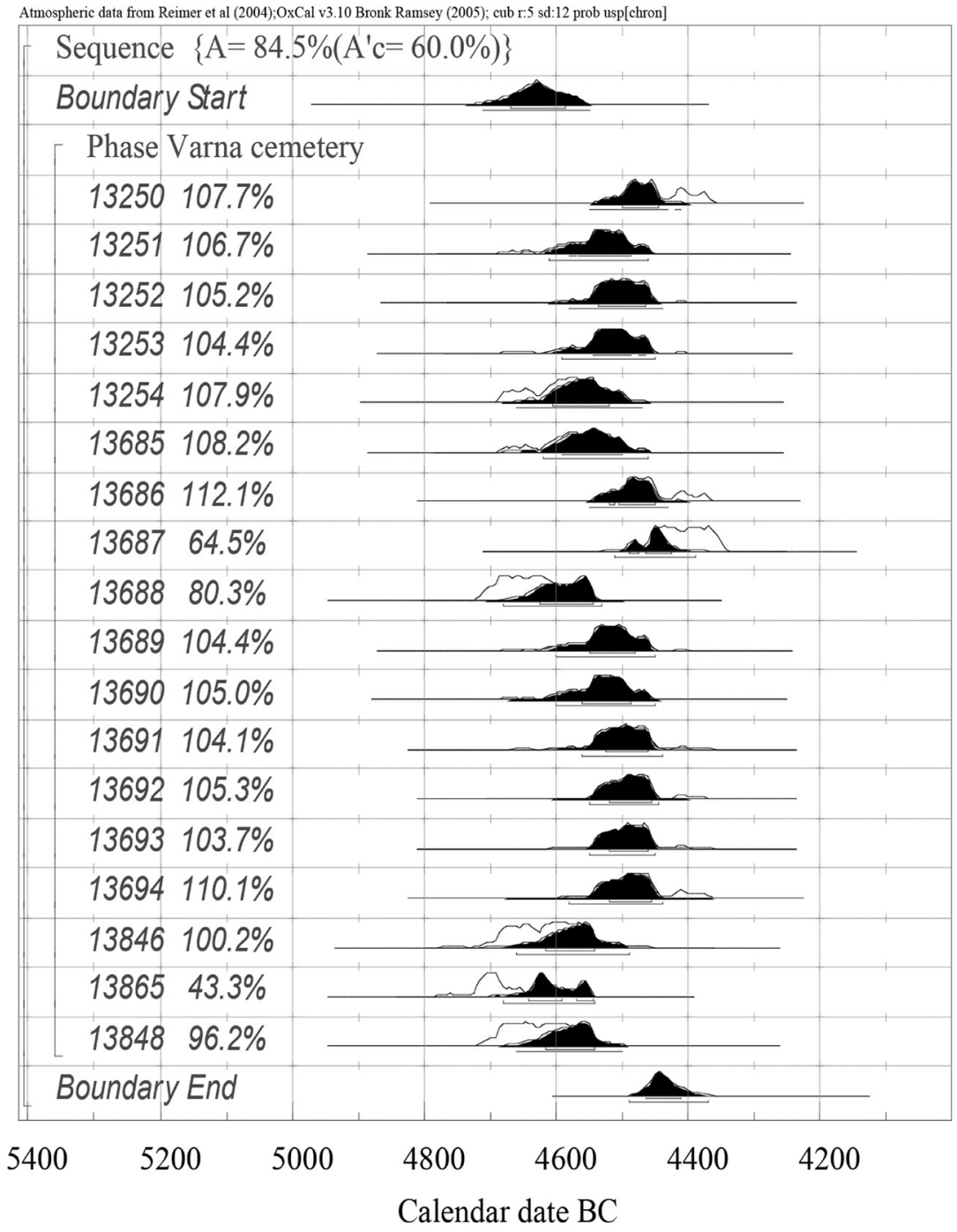

from burials that contained a range of material culture in order to establish temporal relationships between burials as well as investigate aspects of social inequality, a subject that has been particularly important in the regional archaeology (e.g. Chapman 1991; Ivanov 1988; Raduntcheva 1989;
Renfrew 1978; 1986; 2000; Todorova 1986). The Durankulak material was selected for AMS radiocarbon dating with the aim of testing the credibility of the typological chronology established by Todorova (2002a) for all the major phases represented - Hamangia I/II (Late Neolithic), Hamangia III

Table 1. Uncalibrated AMS Dates of Human Bone from Varna I.

\begin{tabular}{|c|c|c|c|c|c|c|c|c|}
\hline Burial No. & OxA No. & Radiocarbon Age BP & $\delta^{13} \mathrm{C}$ & $\mathbf{C N}$ & Weight (mg) & Pret yld (mg) & Wt $\%$ coll & \% carbon \\
\hline 10 & 13687 & $5569 \pm 32$ & -19.1 & 3.2 & 540 & 5.0 & 0.9 & 41.9 \\
\hline 11 & 13686 & $5639 \pm 32$ & -19.3 & 3.2 & 520 & 13.1 & 2.5 & 44.9 \\
\hline 43 & 13685 & $5720 \pm 29$ & -18.5 & 3.2 & 620 & 31.6 & 5.0 & 44.7 \\
\hline 44 & 13692 & $5657 \pm 30$ & -19.1 & 3.2 & 580 & 23.6 & 4.0 & 43.6 \\
\hline 94 & 13250 & $5626 \pm 31$ & -19.3 & 3.2 & 700 & 26.1 & 3.7 & 42.8 \\
\hline 112 & 13251 & $5702 \pm 32$ & -18.6 & 3.1 & 780 & 9.4 & 1.2 & 39.9 \\
\hline 121 & 13252 & $5672 \pm 34$ & -18.9 & 3.2 & 560 & 7.6 & 1.4 & 36.1 \\
\hline 125 & 13253 & $5685 \pm 33$ & -18.6 & 3.0 & 640 & 19.6 & 3.0 & 43.0 \\
\hline 137 & 13694 & $5654 \pm 36$ & -19.8 & 3.2 & 600 & 35.1 & 5.8 & 44.8 \\
\hline 158 & 13688 & $5787 \pm 30$ & -18.9 & 3.3 & 540 & 11.0 & 2.0 & 42.7 \\
\hline 215 & 13691 & $5668 \pm 32$ & -19.8 & 3.2 & 600 & 6.5 & 1.0 & 42.9 \\
\hline 225 & 13693 & $5660 \pm 29$ & -19.8 & 3.2 & 540 & 30.0 & 5.5 & 43.8 \\
\hline 255 & 13254 & $5732 \pm 33$ & -18.6 & 3.2 & 560 & 14.2 & 2.5 & 44.3 \\
\hline
\end{tabular}




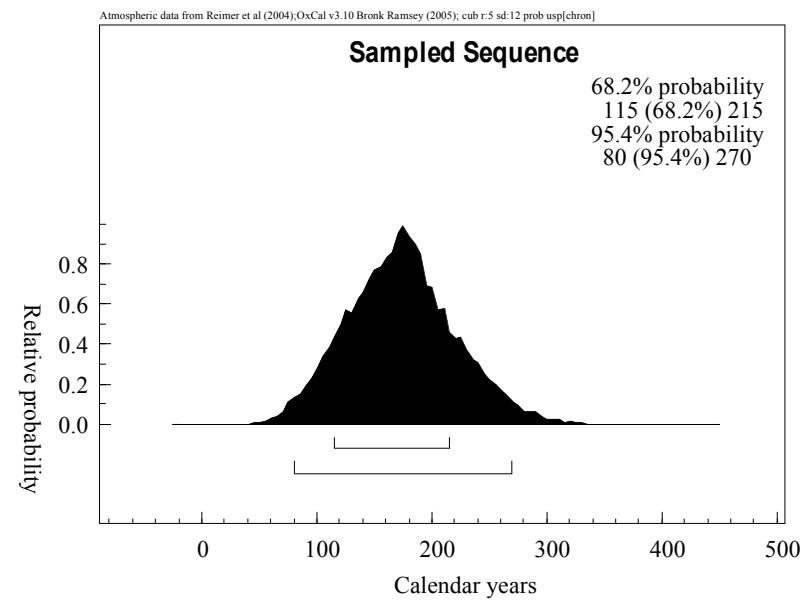

A

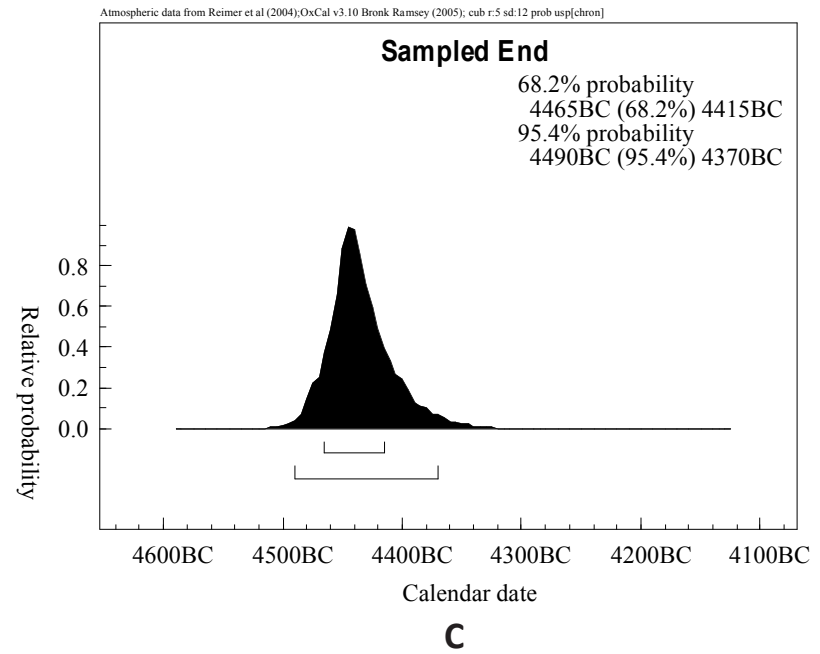

(Early Copper Age), Hamangia IV (Middle Copper Age), Varna I and Varna II-III (all Late Copper Age).

In the absence of stratigraphic information at the Varna cemetery, we modelled the entire corpus of burials as a single phase (Figure 4 and Table 1). All dates were calibrated with OxCal 3.10 (C) Bronk Ramsey 2005) and the IntCal 04 calibration curve (Reimer et al. 2004). The results suggest the cemetery was used for 115-215 years (Figure 5a). The boundary representing the period slightly prior to the cemetery's use falls between 4660 and 4575 BC at $68.2 \%$ probability (Figure $5 \mathrm{~b}$ ). This period corresponds to the end of the Middle Copper Age and the beginning of the Late Copper Age in other parts of Bulgaria (Boyadziev 1995). The boundary representing the end of site use or the terminus ante quem dates to between 4465 and 4415 at $68.2 \%$ prob. (Figure 5c). The cessation of burials occurs during the early part of the Late Copper Age in other regions of Bulgaria (Boyadziev 1995).

The entire corpus of human bone dates from Durankulak is presented in Table 2. With the exception of three young dates (OxA-13695, OxA-13866, OxA-13867), which correspond to the isotopic outliers of the palaeodietary analysis, the samples date to between 5644 (OxA-13868) and 6111 (OxA-

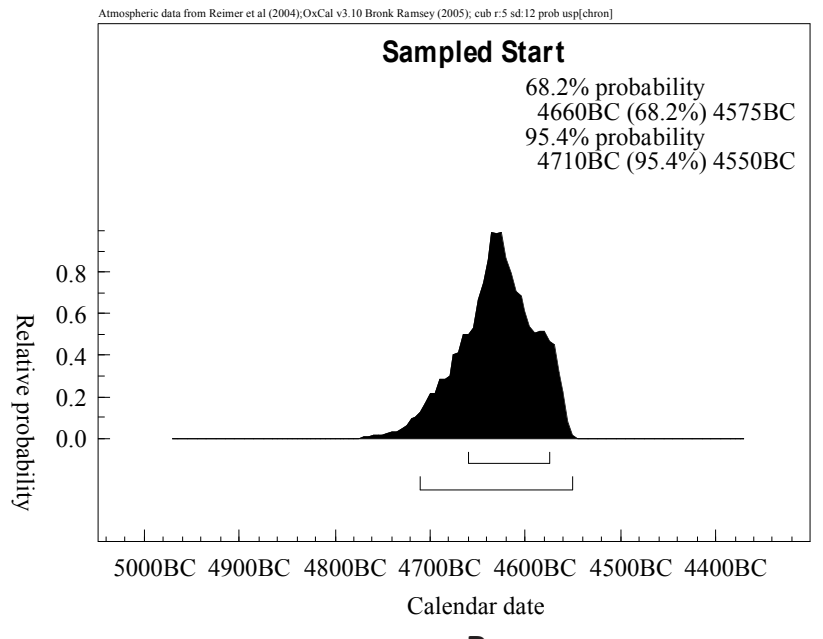

B

Figure 5. Probability distributions for: A - the overall time span represented by the dated burials at Varna $\mathrm{B}$ - the terminus post quem for burials. $\mathrm{C}-$ the terminus ante quem for burials.

13696) radiocarbon years BP. We modelled the Neolithic and Aeneolithic dates according to the mortuary and ceramic typology of Todorova (2002a) (Figure 6). The agreement index of the model was relatively low $(35.8 \%)$, suggesting that the temporal framework was weak. Likelihood probabilities fluctuate significantly between individual dates (18.6 to $109.4 \%$ ), and three samples from Hamangia III and IV did not meet the required threshold of $60 \%$ (OxA-13697, D897; OxA-13868, D509; OxA-13261, D750). While the earliest (Hamangia I/II) and latest phases (Varna I, II/III) adhered to the relative chronology of Todorova (2002a), the intermediate Early and Middle Copper Age burial sequences were less distinct as chronological phases, with significant temporal overlaps.

Acknowledging the fluidity of the dates for the Early and Middle Copper Age at Durankulak, the results suggest the cemetery was used for at least 470 to 650 years in the early to mid-sixth millennium BC (Figure 7). The large variance of the boundary preceding the burials reduces the precision. The boundary marking the termination of the dated burials is relatively small, suggesting the cessation of burials occurred within a 70 year period (at $68.2 \%$ ) around $4450 \mathrm{BC}$. The AMS results suggest the cemetery was probably in use 
Table 2. Uncalibrated AMS Dates of Human Bone from Durankulak.

\begin{tabular}{cccccccccc}
\hline Burial No. & OxA No. & Radiocarbon Age BP & Phase* & $\boldsymbol{\delta}^{13} \mathbf{C}$ & CN & Weight (mg) & Pret yld (mg) & Wt\% coll & \% carbon \\
\hline 4.2 & 13695 & $1170 \pm 24$ & V II-III & -16.7 & 3.2 & 600 & 15.8 & 2.6 & 42.3 \\
27 & 13866 & $1038 \pm 26$ & H III & -14.5 & 3.3 & 740 & 24.1 & 3.6 & 35.2 \\
32 & 13867 & $1187 \pm 25$ & H IV & -15.6 & 3.2 & 720 & 43.8 & 6.1 & 45.0 \\
509 & 13868 & $5644 \pm 35$ & H IV & -19.4 & 3.3 & 740 & 6.0 & 0.8 & 44.1 \\
521 & 13864 & $5745 \pm 45$ & H IV & -19.4 & 3.2 & 780 & 4.5 & 0.6 & 32.6 \\
606 & 13696 & $6111 \pm 32$ & H I-II & -19.3 & 3.2 & 620 & 25.2 & 4.1 & 45.9 \\
693 & 13256 & $5959 \pm 31$ & H III & -18.4 & 3.2 & 540 & 19.6 & 3.6 & 43.4 \\
697 & 13257 & $5992 \pm 29$ & H III & -18.6 & 3.2 & 620 & 13.8 & 2.2 & 42.2 \\
713 & 13258 & $5983 \pm 30$ & H III & -18.4 & 3.2 & 600 & 15.8 & 2.6 \\
714 & 13259 & $6024 \pm 31$ & H III & -18.2 & 3.2 & 520 & 16.3 & 3.1 & 42.3 \\
731 & 13262 & $5681 \pm 30$ & V I & -18.8 & 3.2 & 900 & 36.0 & 4.0 & 44.8 \\
741 & 13367 & $5697 \pm 31$ & V II-III & -18.4 & 3.1 & 920 & 18.6 & 2.0 & 43.3 \\
750 & 13261 & $5979 \pm 30$ & H IV & -18.3 & 3.2 & 580 & 20.0 & 3.4 \\
750 & 13698 & $5879 \pm 33$ & H IV & -19.0 & 3.3 & 600 & 28.6 & 4.8 & 43.6 \\
751 & 13260 & $5996 \pm 31$ & H III & -18.2 & 3.2 & 680 & 23.8 & 3.5 & 44.0 \\
773 & 13255 & $6001 \pm 33$ & H I -II & -18.5 & 3.2 & 600 & 15.7 & 2.6 & 43.7 \\
822 & 13368 & $5907 \pm 34$ & V & -18.5 & 3.1 & 680 & 18.5 & 2.7 \\
826 & 13263 & $5658 \pm 31$ & V II-III & -18.8 & 3.2 & 920 & 13.7 & 40.5 \\
897 & 13697 & $5783 \pm 30$ & H III & -19.3 & 3.3 & 640 & 22.6 & 3.5 & 42.6 \\
\hline
\end{tabular}

* Phase: "H" and "V" refer to "Hamangia" and "Varna", respectively. Burials are categorised with respect to the ceramic typology of Todorova (2002a).

Figure 6. Probability distributions of calibrated dates from Durankulak Burials using Bayesian statistics. The columns to the left-hand side of the table contain the 5-digit lab numbers (OxA-) used by the Radiocarbon Accelerator Unit, Oxford, and indices of acceptability, respectively Individual dates or sequences of dates are deemed acceptable if their index of acceptance meets or exceeds $60 \%$. Burial 822 (OxA-13368) is omitted from the model since it is only assigned to "Varna Age" in the general sense; its associated radiocarbon date is also likely too early for "Varna Age" material.

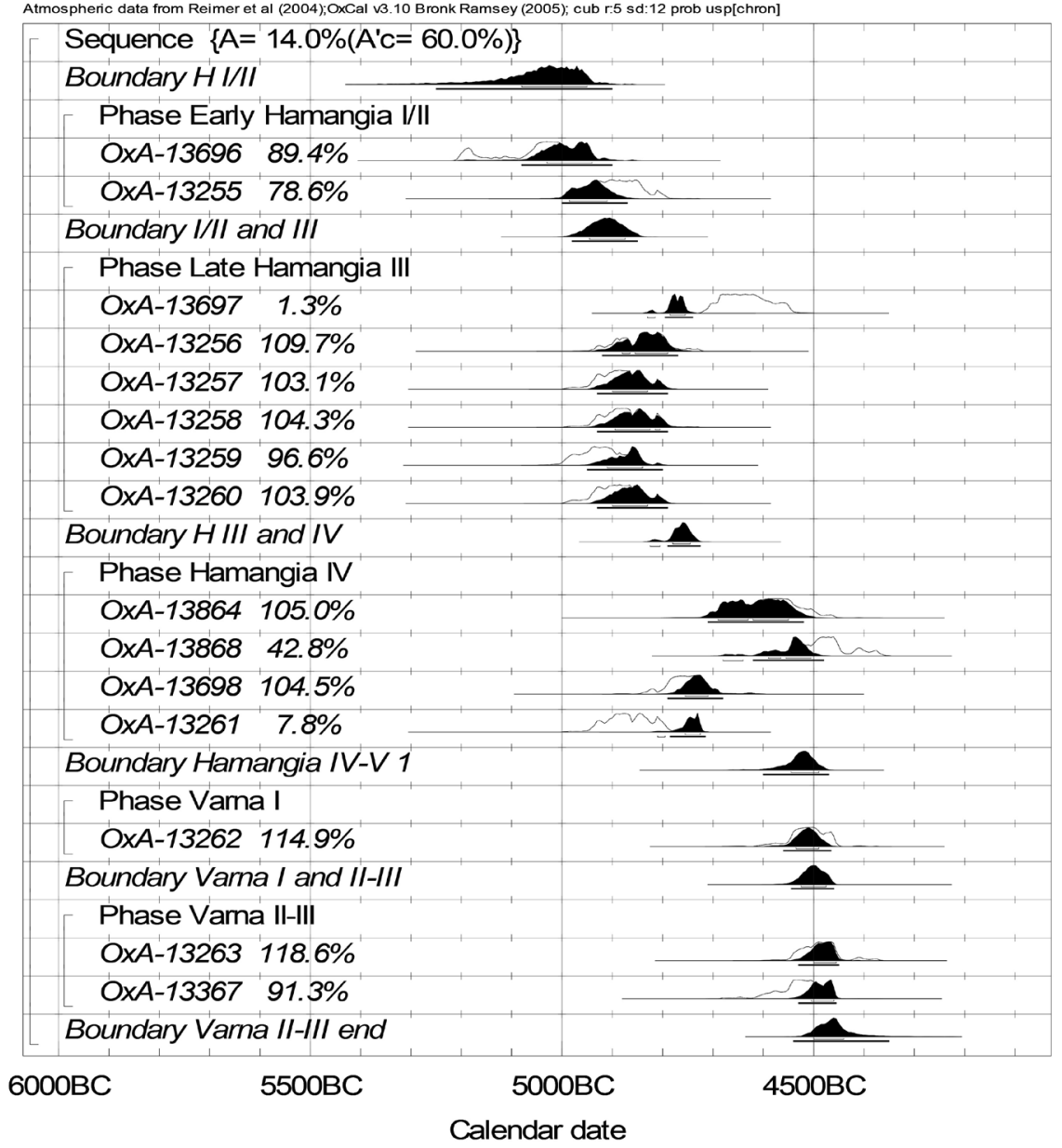




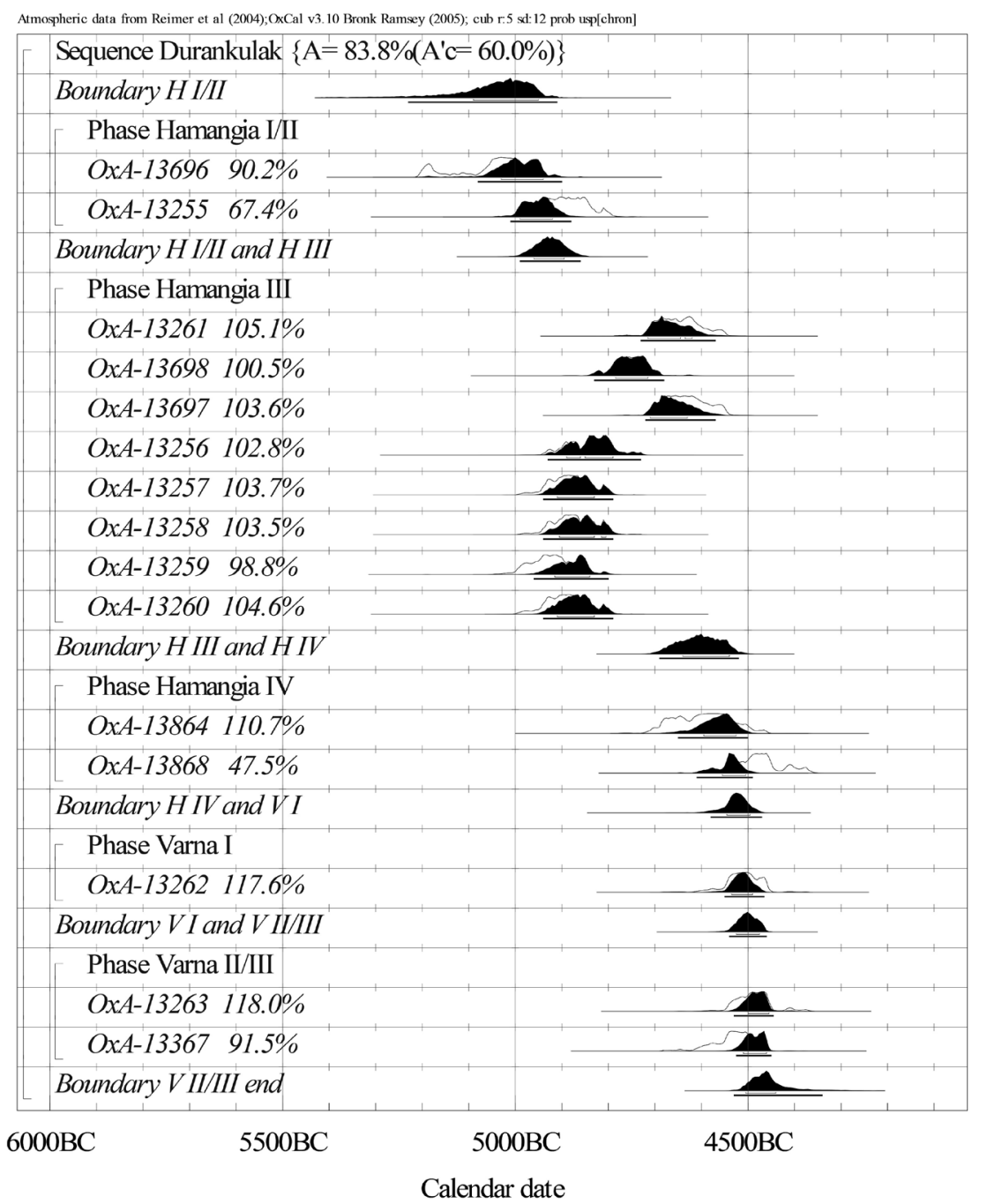

Figure 7. Probability distributions of calibrated dates from Durankulak burials using Bayesian statistics. OxA samples 13261 and 13698 were moved from Hamangia IV, where they were classified by Todorova et al. (2002), to Hamangia III, since the pottery appeared to be non-diagnostic and, thus, questionably categorised. The columns to the left-hand side of the table contain the 5-digit identification numbers (OxA-) used by the Radiocarbon Accelerator Unit, Oxford, and indices of acceptability, respectively. Individual dates or sequences of dates are deemed acceptable if their index of acceptance meets or exceeds $60 \%$. by $5000 \mathrm{BC}$, in the Late Neolithic period in Bulgaria, and had gone out of use around approximately $4450 \mathrm{BC}$, at an early stage of the Late Aeneolithic in other parts of Bulgaria (Boyadziev 1995).

\subsection{Animal Isotope Values}

The isotope values of the 26 faunal samples from Varna and Durankulak are presented in Figure 8 and Table 3.
The $\delta^{13} \mathrm{C}$ values of the herbivorous mammals (Bos $s p$., C. elaphus, Equus sp., ovicaprids) range between -20.8 and $-17.7 \%$, and are similar to Neolithic (Iacumin et al. 2004), Aeneolithic and later Bronze and Iron Age fauna from the Black Sea region (Privat 2004) (Table 3). The $\delta^{13} \mathrm{C}$ values of the Bronze Age tortoise are comparable to humans $(\sim-12$ to $-13 \%)$ and animals that consume substantial quantities of marine resources (Cannon et al. 1999; Chisholm et al.

Table 3. Averaged Results of Stable Isotope Analysis $\left(\delta^{13} \mathrm{C}\right.$ and $\left.\delta^{15} \mathrm{~N}\right)$ for Acceptable Animal Bone Collagen by Taxonomic Group.

\begin{tabular}{|c|c|c|c|c|c|c|}
\hline \multirow[b]{2}{*}{ Species } & \multirow[b]{2}{*}{ Description } & \multirow[b]{2}{*}{$\mathbf{N}$} & \multicolumn{2}{|c|}{$\begin{array}{c}\text { Carbon from collagen } \\
\qquad \delta^{13} \mathrm{C}(\%)\end{array}$} & \multicolumn{2}{|c|}{$\begin{array}{c}\text { Nitrogen from collagen } \\
\qquad \delta^{15} \mathrm{~N}(\% \%)\end{array}$} \\
\hline & & & Mean & S.D. & Mean & S.D. \\
\hline Meles meles & Old World Badger & 1 & -18.3 & $\mathrm{~N} / \mathrm{A}$ & 10.0 & $\mathrm{~N} / \mathrm{A}$ \\
\hline Bos sp. & Cattle & 7 & -19.6 & 0.3 & 6.1 & 0.5 \\
\hline Canid sp. & Dog & 3 & -18.7 & 0.2 & 9.2 & 0.8 \\
\hline Cervus elaphus & Red deer & 1 & -20.1 & $\mathrm{~N} / \mathrm{A}$ & 5.3 & $\mathrm{~N} / \mathrm{A}$ \\
\hline Equus sp. & Horse & 1 & -19.5 & $\mathrm{~N} / \mathrm{A}$ & 6.4 & $\mathrm{~N} / \mathrm{A}$ \\
\hline Equus asinus hydruntinus & European "wild ass" & 4 & -20.8 & 0.1 & 3.6 & 0.1 \\
\hline Vulpes sp. & Fox & 2 & -19.1 & 0.6 & 8.0 & 0.2 \\
\hline Ovis/Capra & Sheep/goat & 5 & -18.8 & 0.6 & 8.2 & 1.7 \\
\hline Unknown & Bronze Age Tortoise & 1 & -14.1 & $\mathrm{~N} / \mathrm{A}$ & 14.8 & $\mathrm{~N} / \mathrm{A}$ \\
\hline
\end{tabular}




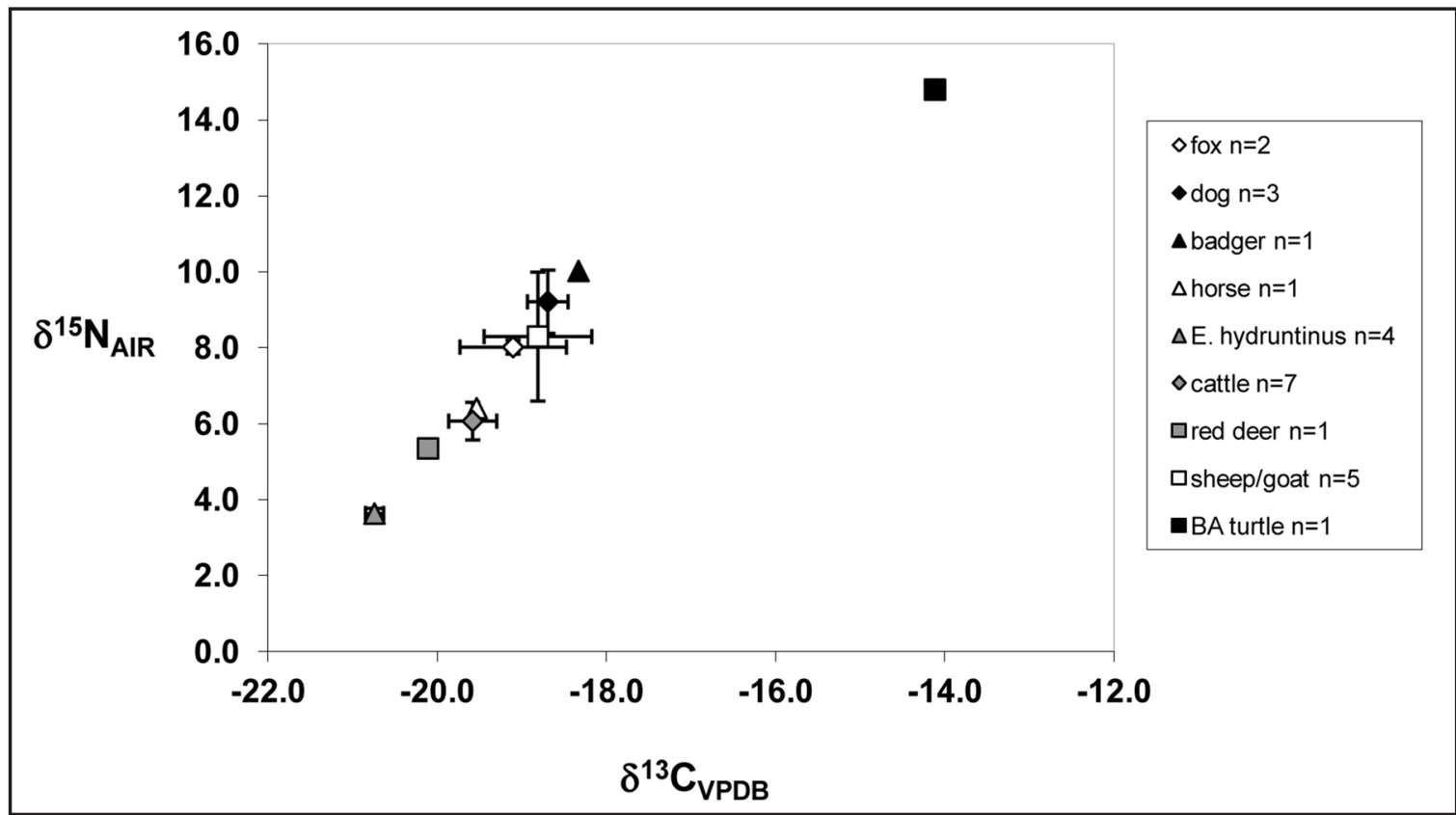

Figure 8. Carbon and nitrogen stable isotope ratios for collagen from animal bone collected from the Durankulak and Varna I cemeteries. 26 samples are represented.

1982). The result is consistent with current knowledge about marine environments and the high $\delta^{13} \mathrm{C}$ value is probably linked to the dissolved carbonate and bicarbonate of prominent carbon sources in marine foodwebs (Katzenberg, Weber 1999).

The mean $\delta^{15} \mathrm{~N}$ values of the cattle, horse and deer (5.3$6.4 \%)$ are lower than the omnivores/carnivores (8-10\%), demonstrating a trophic level effect of approximately $3 \%$. The average $\delta^{15} \mathrm{~N}$ values of Canis $s p$. (9.2\%) and Vulpes $s p$. $(8 \%)$ are analogous to values from the same species found at inland sites in the Ukraine (Table 3).

The ovicaprids show a higher variation in $\delta^{13} \mathrm{C}$ and $\delta^{15} \mathrm{~N}$ values relative to the other herbivores. Most ovicaprids (3-4 individuals) also have high $\delta^{15} \mathrm{~N}$ values relative to the other herbivores, falling within the range of foxes and dogs. By comparison, ovicaprids from inland sites $500 \mathrm{~km}$ Northeast of Varna and Durankulak show $\delta^{15} \mathrm{~N}$ values that are lower by $2 \%$. The high ovicaprid $\delta^{15} \mathrm{~N}$ values in this study could be related to water stress or differential climatic conditions relative to the Ukraine. However, isotopic studies of sheep hair keratin have shown that sheep that graze in urban or physically constrained areas in Turkey have higher $\delta^{15} \mathrm{~N}$ values relative to sheep that graze in open or rural contexts (Hull et al. 2005). This phenomenon is probably a factor of natural manuring and the increased nitrification of soils in contained grazing areas. If the ovicaprids were grazed in contained areas in and around the Durankulak tell settlement, this treatment could explain the high $\delta^{15} \mathrm{~N}$ values in ovicaprids from the site. Currently, the reported $\delta^{15} \mathrm{~N}$ values represent the entirety of ovicaprid samples from the Black Sea region, and a clear understanding of isotopic variability will require the analysis of more samples.

\subsection{Human Isotope Values}

The $\delta^{13} \mathrm{C}$ values of the Varna humans range from -20 to $-18.5 \%$, with a population average of $-19.3 \pm 0.3 \%(n=55)$. Burials no 43 and 51 exhibit higher $\delta^{13} \mathrm{C}$ and $\delta^{15} \mathrm{~N}$ values (more than $2 \mathrm{~s}$ above the mean) relative to the rest of the population (Figure 9 and Table 4). The $\delta^{15} \mathrm{~N}$ values range from +8.7 to $+11.3 \%$, with a population average of $+10.0 \pm 0.6$, which is at least $3 \%$ above the non-ovicaprid herbivores and in the range of the canids, foxes and badger. The $\delta^{13} \mathrm{C}$ values of the Durankulak humans range from -19.8 to $-18.6 \%$, averaging $-19.1 \pm 0.3 \%$, and the $\delta^{15} \mathrm{~N}$ values range between +7.6 to $+11.5 \%$, averaging $+9.3 \pm 0.8 \%(\mathrm{n}=78)$ (Figure 10 and Table 5).

Although the $\delta^{13} \mathrm{C}$ values of both populations are slightly higher than typical $\delta^{13} \mathrm{C}$ values of human populations from inland Neolithic populations in Europe (c. -21 to $-22 \%$ ), this difference is probably attributable to climate. Large scale investigations of $\delta^{13} \mathrm{C}$ values of wood, charcoal, and bone samples taken from a variety of sites in Europe have shown that $\delta^{13} \mathrm{C}$ values tend to increase in a north to south direction following the climatic/temperature cline toward the Mediterranean and the Black Sea (van Klinken et al. 1994; 2000). In this context, the isotope data from Varna and Durankulak again suggests the human populations primarily utilised terrestrial, $\mathrm{C}_{3}$-based diets, but perhaps with varying amounts of animal protein.

Potential sources of terrestrial food are commonly found in the faunal record of the Durankulak cemetery, which includes wild species, such as Equus (Asinus) hydruntinus, Cervus elaphus, Capreolus capreolus, Sus scrofa and Bos primigenius, as well as domesticated species such as ovicaprids and Bos taurus (Spassov, Iliev 2002). A further nine wild taxa were found in the Copper Age tell at 

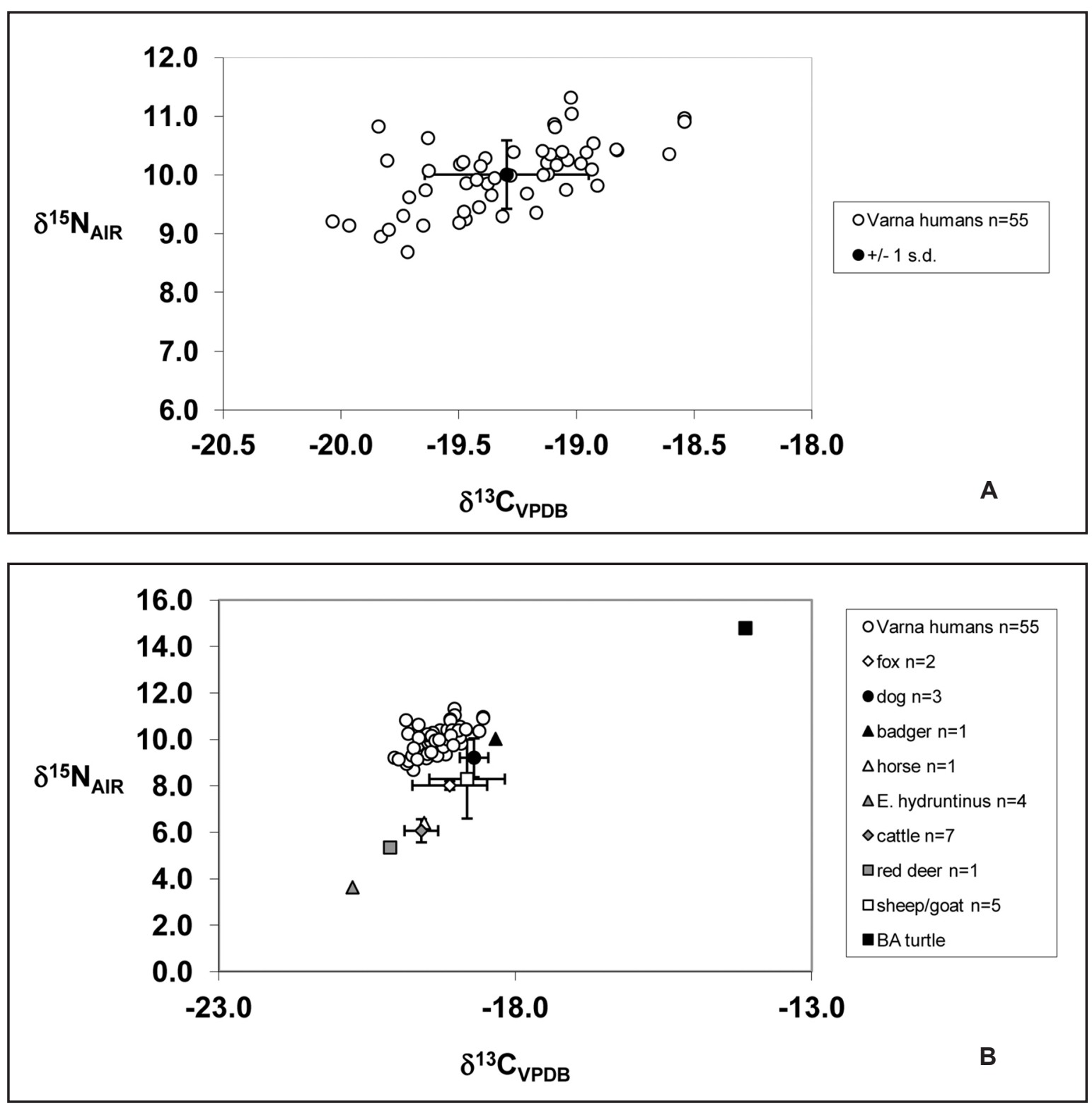

Figure 9. A - Distribution of acceptable stable isotope values from Varna human bone collagen. B - Distribution of A with respect to acceptable stable isotope values of animal bone.

Table 4. Averaged Results of $\delta^{13} \mathrm{C}$ and $\delta^{15} \mathrm{~N}$ Stable Isotope Analysis for Human Bone from Varna.

\begin{tabular}{cccccc}
\hline & \multicolumn{2}{c}{ Carbon from collagen } & & \multicolumn{2}{c}{ Nitrogen from collagen } \\
& \multicolumn{2}{c}{$\boldsymbol{\delta}^{\mathbf{1 3}} \mathbf{C}$} & & & \multicolumn{2}{c}{$\boldsymbol{\delta}^{\mathbf{1 5}} \mathbf{N}$} \\
\cline { 2 - 3 } \cline { 5 - 6 } $\mathbf{N}$ & Mean & S.D & & Mean & S.D. \\
\hline 55 & -19.3 & 0.3 & & 10.0 & 0.6 \\
\hline
\end{tabular}

Durankulak (Manhart 1998), some of which were deposited as grave goods. Between the earlier Hamangia I-II and later Aeneolithic graves at Durankulak, there appears to be an increased presence of domesticated animals remains as grave goods, and the move away from wild fauna such as Equus (Asinus) hydruntinus.

Evidence for local cereal cultivation is derived from two sources: pollen and plant macro-fossils. Aeneolithic sediments form the Durankulak-2 pollen core include pollen and grains of Triticum sp. (wheat) and Hordeum sp. (barley), as well as primary indicators of cultivation and disturbed ground (e.g., Plantago lanceolata and Polygonum aviculare) (Božilova, Tonkov 1998; 2002). Plant macrofossils recovered from the Neolithic and Aeneolithic occupation at Durankulak have been identified by Popova (1995: Table 4, 201, 203) as einkorn, emmer wheat, bread wheat, club wheat and spelt wheat, naked barley, millet, lentils, vetch, peas, wild grape pips and several weeds of cultivation (incl. Polygonum aviculare, as found in the pollen spectra). A cake of sorrel seeds (Rumex acetossella $L$.) was also recovered from Hamangia III grave D 194 (Popova 1995, 203).

Although cereals clearly contributed to Neolithic and Aeneolithic diets, it is difficult to assess the relative importance of cereals versus other food sources from the perspective 


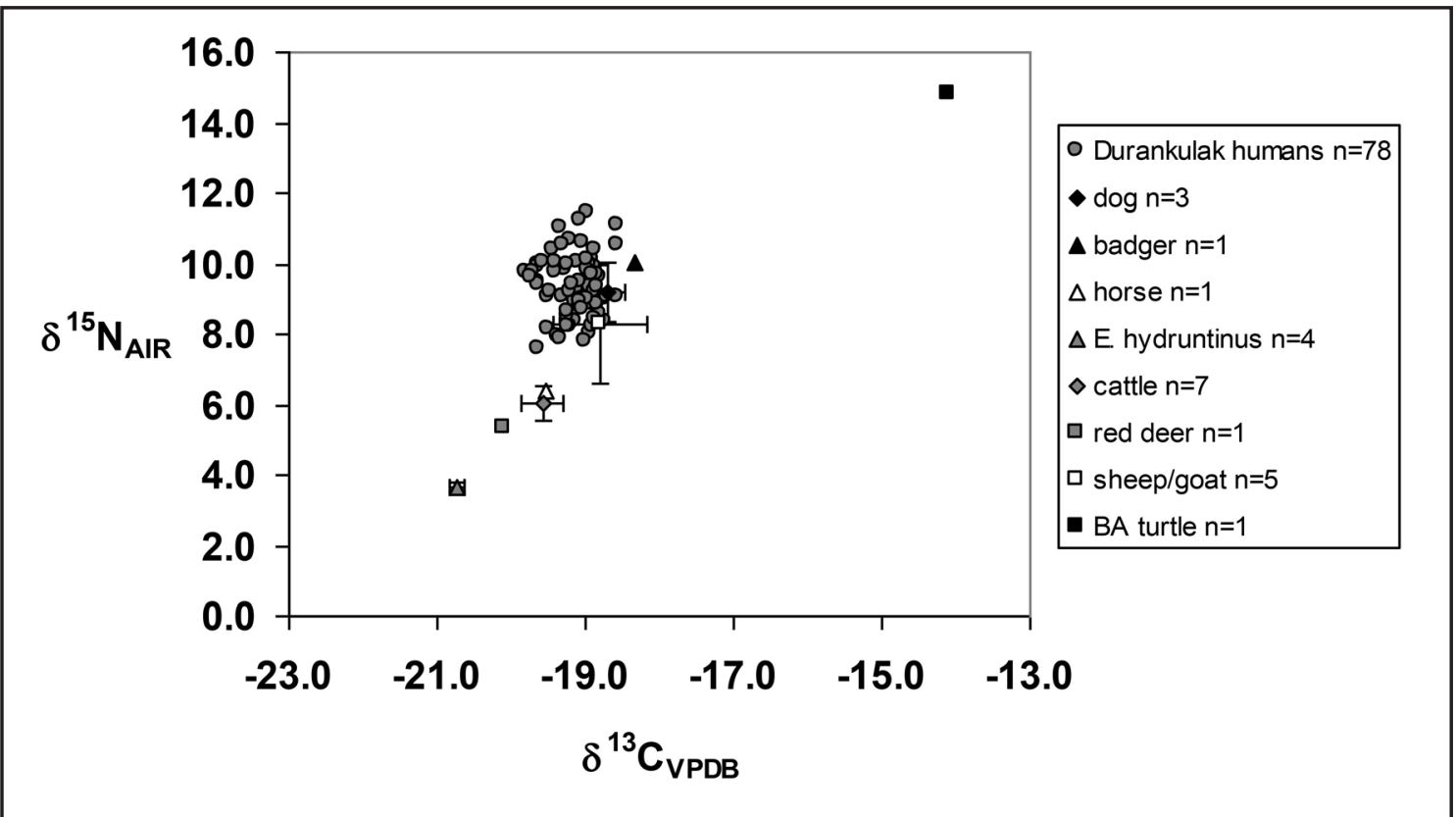

Figure 10. Distribution of acceptable stable isotope values for Durankulak human bone collagen relative to animals.

Table 5. Averaged Results of Stable Isotope Analysis $\left(\delta^{13} \mathrm{C}\right.$ and $\left.\delta^{15} \mathrm{~N}\right)$ for Acceptable Human Bone from Durankulak.

\begin{tabular}{|c|c|c|c|c|c|}
\hline & \multirow[b]{2}{*}{$\mathbf{N}$} & \multicolumn{2}{|c|}{$\begin{array}{c}\text { Carbon from collagen } \\
\qquad \delta^{13} \mathrm{C}\end{array}$} & \multicolumn{2}{|c|}{$\begin{array}{c}\text { Nitrogen from collagen } \\
\qquad \delta^{15} \mathrm{~N}\end{array}$} \\
\hline & & Mean & S.D. & Mean & S.D. \\
\hline Central Cluster & 78 & -19.1 & 0.3 & 9.3 & 0.8 \\
\hline Isotopic Outliers & 5 & -16.0 & 0.4 & 10.9 & 1.1 \\
\hline
\end{tabular}

of bulk collagen, which tends to reflect the stable isotope chemistry of dietary protein. It is hoped that future work at the level of single amino acids will be able to provide information about carbohydrate and lipid fractions of the diet.

The spatial distribution of $\delta^{13} \mathrm{C}$ and $\delta^{15} \mathrm{~N}$ values differs between the Varna and Durankulak populations (Figure 11). Whilst there is no systematic correlation between the $\delta^{13} \mathrm{C}$ and $\delta^{15} \mathrm{~N}$ values of the Durankulak humans $(\mathrm{R}=0.012 ; \mathrm{p}=0.92)$, there is a moderately strong linear relationship exhibited by the Varna humans $(\mathrm{R}=0.61, \mathrm{p}<0.001)$, with a $\delta^{15} \mathrm{~N}: \delta^{13} \mathrm{C}$ slope of approximately 1 . A linear gradient of 2 has been observed between Neolithic populations in Europe, which utilised terrestrial food resources, and earlier Mesolithic populations, which primarily utilised marine resources (Lubell et al. 1994; Richards et al. 1999). This relationship is consistent with the preferential routing of dietary protein to bone collagen (as opposed to de novo synthesis) when the intake of dietary protein is rather high. It is well attested that marine food sources are relatively protein rich and have higher $\delta^{13} \mathrm{C}$ and $\delta^{15} \mathrm{~N}$ values compared to terrestrial sources (Richards, Hedges 1999; Schoeninger, DeNiro 1984; Tauber 1981). Accordingly, where marine resources are exploited, and depending on the degree to which they were utilised, it would be expected that bulk collagen $\delta^{13} \mathrm{C}$ and $\delta^{15} \mathrm{~N}$ values should be higher compared to terrestrial consuming populations.
Although terrestrial diets with high levels of animal protein (but with no marine protein) should also have high $\delta^{15} \mathrm{~N}$ values, one would not expect substantially higher $\delta^{13} \mathrm{C}$ values relative to terrestrial diets with comparatively low amounts of animal derived protein.

The Varna isotope values suggest that there was a continuum of dietary protein sources ranging from primarily terrestrial $\mathrm{C}_{3}$ protein, derived from plants and terrestrial fauna, to a combination of mostly terrestrial $\mathrm{C}_{3}$ protein and a small but detectable component of marine protein. The former is represented by individuals with $\delta^{15} \mathrm{~N}$ and $\delta^{13} \mathrm{C}$ values that are $-1 \sigma$ lower than the population mean, whilst the latter is represented by individuals such as burials no 43 and 51 (Figure 9). Overall, however, despite the proximity to the Black Sea, the Varna humans do not appear to have utilised marine resources to any significant extent.

If individuals were consuming marine protein, one would expect to observe radiocarbon offsets between cointerred human and terrestrial animal remains, similar to the phenomenon demonstrated at Mesolithic and Neolithic sites along the Danube (Bonsall et al. 1997; Cook et al. 2001), even though the underlying geochemical mechanics differ between the Danube and Black Sea. The AMS dating of select human-terrestrial animal pairs from Varna suggests that there is a low probability of offset from true age between 


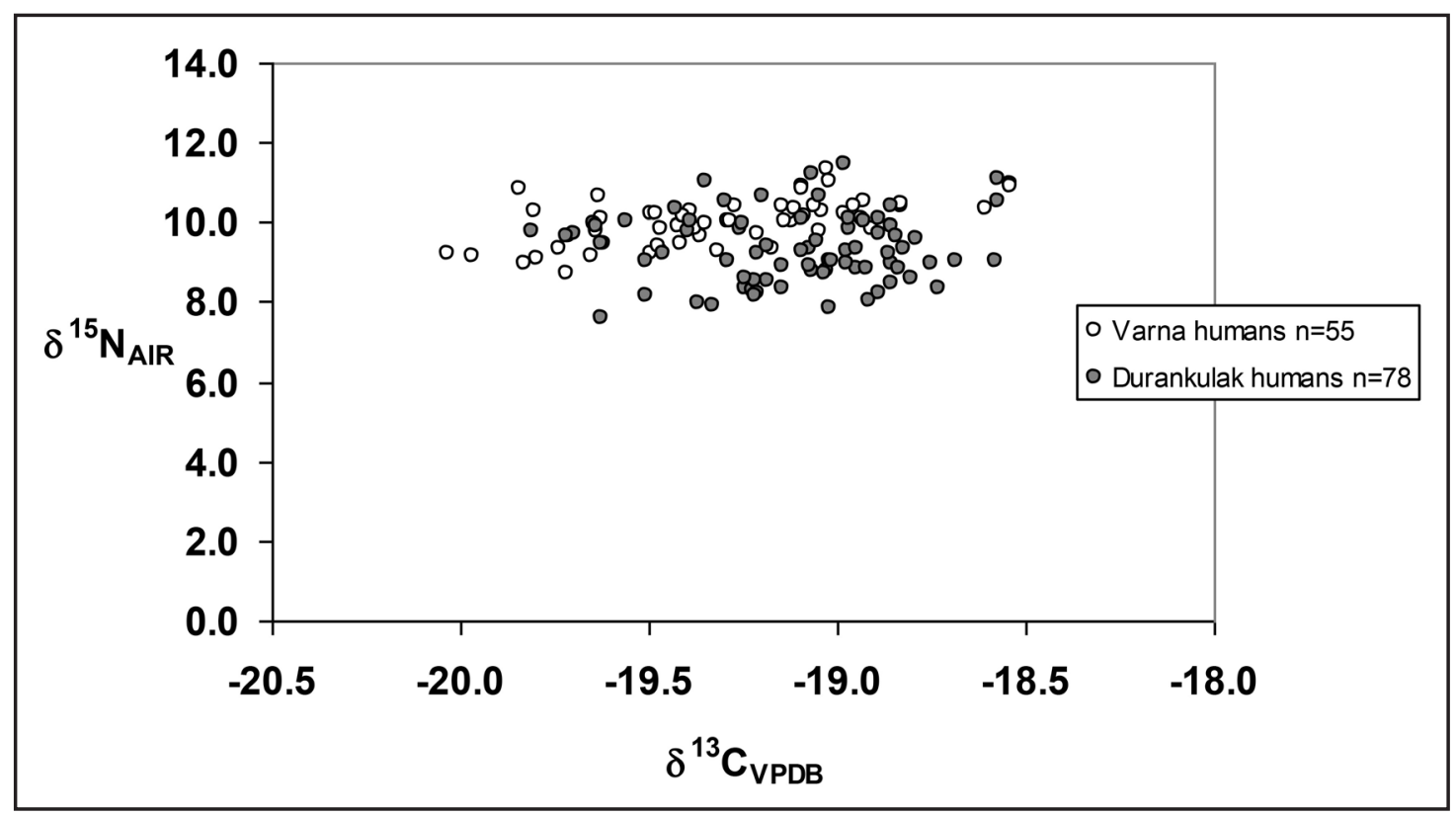

Figure 11. Comparative plot of stable isotope measurements for the human populations of Varna and Durankulak.

the samples due to reservoir effects, meaning little to no dietary protein was derived from marine resources by the Varna humans.

Although there is no correlation between the $\delta^{13} \mathrm{C}$ and $\delta^{15} \mathrm{~N}$ values for the Durankulak humans, there is a large range of $\delta^{15} \mathrm{~N}$ values $(+7.6$ to $+11.5 \%$ ). Almost a quarter of the Durankulak humans have lower $\delta^{15} \mathrm{~N}$ values than the lowest Varna $\delta^{15} \mathrm{~N}$ value. In addition, the $\delta^{15} \mathrm{~N}$ values of these humans are less than 3\% higher than the Bos sp. average. The intra-population variation of $\delta^{15} \mathrm{~N}$ values is probably due to the differential utilisation of terrestrial $\mathrm{C}_{3}$ protein. Those with lower $\delta^{15} \mathrm{~N}$ values did not consume as much meat or secondary animal products (e.g. milk, cheese) as those with higher $\delta^{15} \mathrm{~N}$ values, such as the humans in burials D532 (+11.5\%), D643 (+10.5\%), and D731 (+11.0\%). Humans with higher $\delta^{15} \mathrm{~N}$ values, which tend to be $2-3 \%$ higher than the ovicaprids, probably consumed more meat and/or secondary products from sheep/goats, in addition to consuming the same types of terrestrial and $\mathrm{C}_{3}$ plants that were also consumed by individuals with lower $\delta^{15} \mathrm{~N}$ values. The $\delta^{13} \mathrm{C}$ values of D532, D643, and D731 are close to the population mean of $-19.1 \%$, suggesting that their $\delta^{15} \mathrm{~N}$ values are not linked to marine protein consumption. However, Durankulak burials D193 and D595 exhibit $\delta^{13} \mathrm{C}$ and $\delta^{15} \mathrm{~N}$ values akin to Varna burials V43 and V51, suggesting that a small number of Durankulak humans did supplement their diets with marine resources over long enough periods to register in the bone collagen.

\subsection{Varna and the Question of Social Power and Emergent Hierarchies}

The unequal distribution of the large gold assemblage at Varna is often argued to be a manifestation of social hierarchies in the Eastern Balkans (e.g. Ivanov 2000; Renfrew 1986; Sandars 1985; Chapman 2012; cf. views against hierarchy in Whittle 1996; Bailey 2000; Kienlin 2012). However, the modern perception of the value and prestige of gold should not imply that a similar view was pervasive in prehistory (Parker Pearson 1999). Renfrew (1986) advances five credible reasons for the perceived value of the Varna gold in prehistory on the basis of archaeological evidence:

1. The gold is consistently used for personal adornment in the proximity of two positions of the body that are important cross-culturally: the face and the genitals.

2. The gold is used in objects of prime symbolic value, such as "maces" and "sceptres".

3. Objects are made to appear as if they are made of gold when they are not (i.e. to make the objects appear more valuable).

4. Gold is used more economically than other materials: copper and other metallic artefacts are solid throughout, whereas gold is usually applied to surfaces in thin sheets, to maximize surface area per unit weight.

5. Gold is inherently attractive in the sense that it reflects light efficiently and is resistant to oxidation, making it an enduring, relatively incorruptible material.

After promising early research (Eluère 1989), further scientific investigation of gold artefacts and/or their impurities is currently under way, as is detailed field prospection for the source(s) of the Varna gold. However, the lead isotope analysis of copper objects has indicated that copper ores were obtained from Medni Rid (Burgas, Bulgaria), Ai Bunar (Stara Zagora, Bulgaria) and from the Majdanpek area of Serbia (Gale et al. 2000). In combination with evidence from other material culture from the site, such as carnelian, jadeite, nephrite, Spondylus and Dentalium, the existence of long-ranging trading networks is clear. The closest known carnelian source is the North Levant and the nephrite used in axe heads was probably derived from sources in Afghanistan (Kostov, Bakumska 2004; Kostov 2004). The petrological 


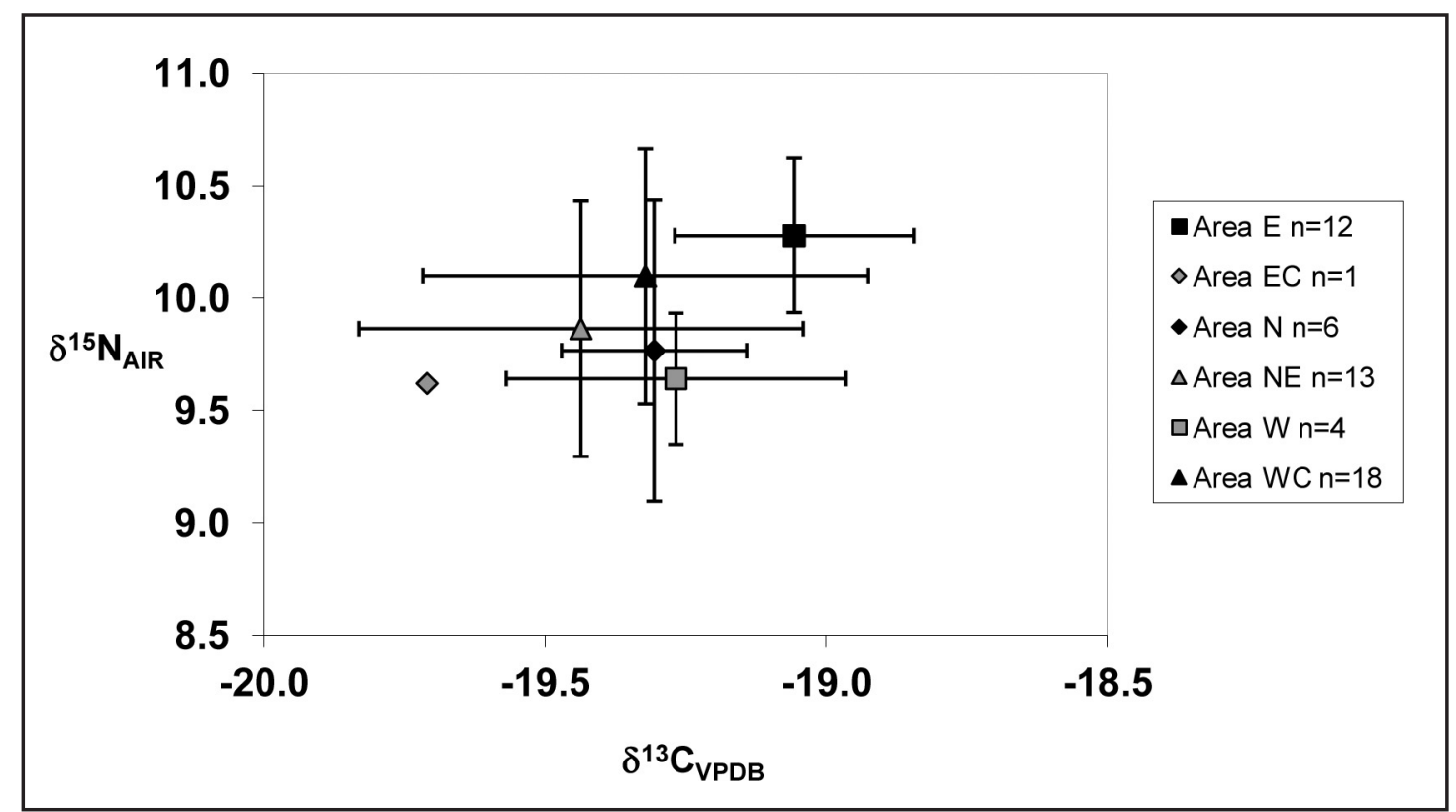

Figure 12. Acceptable stable isotope values for Varna humans with respect to the spatial clustering of graves.

analysis of the jadeite axes from burial no 4 indicates that they were likely sourced from Monte Viso in the Italian Alps (Pétrequin et al. 2012). The majority of Spondylus shell rings and pendants, and Dentalium beads, likely originated in the Aegean (Chapman 2004). The intersection of longdistance trade networks and marked differences in material wealth at Varna, at least at death, is potential evidence for the emergence of social ranking. If social hierarchies or power structures existed by the Late Aeneolithic, the control and differential access to resources were likely important.

In relation to diet, those in positions of power - whether it be material, ideological or otherwise - may have had access to foods that others in the community did not, a well attested phenomenon in the ethnographic record (Gumerman 1997). If such differential access existed long-term, there may be detectable isotopic differences between the various diets, and therefore a relationship between diet and the inferred wealth of individuals.

If the number and type of grave goods are credible indicators of the wealth or status of individuals at Varna, individual V43 (number of grave goods: 1013; types of grave goods: 25) and individual V51 (number of grave goods: 16; types of grave goods: 7) would have been important. Burial V43, the most elaborate burial at Varna, contained over 990 gold artefacts, weighing $1.5 \mathrm{~kg}$ in total, including necklaces, earrings, bracelets, a copper adze with gold rings, and a gold penis sheath, in addition to other artefacts. In light of its material wealth, burial V43 has been characterised as everything from a chieftain to a king (Ivanov 2000; Sandars 1985). These individuals have $\delta^{13} \mathrm{C}$ values that are more than two standard deviations above the population mean, and the third and fourth highest $\delta^{15} \mathrm{~N}$ values, suggesting that there may be a relationship between material wealth and high $\delta^{13} \mathrm{C}$ and $\delta^{15} \mathrm{~N}$ values which could
Table 6. General Linear Model of Varna Isotope Values vs Number and Distinct Types of Grave Goods.

\begin{tabular}{lc}
\hline \multicolumn{1}{c}{ Variables } & P \\
\hline$\delta^{13} \mathrm{C}$ vs Grave Good Number & 0.079 \\
$\delta^{13} \mathrm{C}$ vs Grave Good Types & 0.055
\end{tabular}

reflect long-term dietary differences from other individuals interred at Varna.

At the population level, however, statistical analyses suggest there is no correlation between stable isotope values and the number or types of grave goods associated with individual burials (Table 6). The presumed significance of Varna burials V43 and V51 also diminishes with respect to comparisons with the Durankulak burials, many of which have similar $\delta^{13} \mathrm{C}$ and $\delta^{15} \mathrm{~N}$ values but lack material remains (see Figure 11). Overall, there is little reason to suggest that individuals associated with larger assemblages of artefacts had consistent, long-term access to foods and that others in the community did not. Neither is there any clear correlation between isotopic values and the spatial distribution of graves at Varna (Figure 12).

This may be due not only to the limited resolution of stable isotope data but also to the theoretical complexities of status, be it social, political, religious, or economic, and its assignation to prehistoric humans on the basis of material remains. Although the individuals in this study must have maintained a sufficient local connection to have warranted their burial at Varna or Durankulak, it is possible that some individuals originated from distant regions or were local in origin but travelled to other regions during their lives (e.g. as traders or individuals of prominent economic/political standing). Some of the observed isotope variation at Varna and Durankulak may be due to the consumption of food from 
a variety of geographic regions or the exposure to climatic or environmental influences that were different from the local area. This might be particularly true at Varna, which is not affiliated with a settlement. However, it is the Durankulak burials, which are associated with a settlement, that show greater isotopic variability. The Durankulak cemetery is much larger and was in use for much longer than Varna; it is possible that such variability is the result of dietary changes that are not currently apparent due to the limited ability of the few radiocarbon dates $(n=19)$ to separate the isotope data into smaller temporal units.

This does not necessarily mean that individuals V43 and V51 were not powerful or respected élites. If they were, however, it is clear that their positions did not entail any long-term access to unique sources of dietary protein. It cannot be ruled out that these individuals had short-term or sporadic access to particular foods, the results of which are not detectable via SIA. It is also possible that individuals had access to unique plant-based foods, but that the isotope values of such low-protein foods would not influence the bulk bone collagen isotope values as easily as animal-based protein. This is a limitation of the bulk SIA technique.

\section{Conclusions}

The $\delta^{13} \mathrm{C}$ and $\delta^{15} \mathrm{~N}$ data from Varna and Durankulak suggest both populations maintained terrestrial, C3 diets, where dietary protein was derived primarily from terrestrial animals and/or animal products. The isotopic datasets from both sites are similar to Neolithic contexts in Western and Central Europe (coastal and inland), where it is relatively certain that certain terrestrial, C3-based diets were the norm.

The dated human-animal pairs from Varna, although not ideal, suggest the Black Sea reservoir effect has not influenced the dates of the larger population and, by extension, that of Durankulak. This conclusion is consistent with the stable isotopic data, which suggests the consumption of marine resources was minimal at both sites. More testing is required.

Thus, regardless of their proximity to the Black Sea, it appears the populations of Varna and Durankulak did not consume marine resources to any significant degree. The isotopic values of individuals show little similarity to those of Mesolithic Brittany (Schulting, Richards 2001), the Dniepr Rapids (Lillie, Richards 2000) and the Iron Gates Gorge (Bonsall et al. 1997), where the consumption of marine and freshwater resources is confirmed.

The five isotopic outliers from Durankulak had diets that were considerably different from the rest of the population. With respect to $\delta^{13} \mathrm{C}$ and $\delta^{15} \mathrm{~N}$ values, these Medieval individuals are similar yet slightly depleted compared to those of Mesolithic Téviec, in Brittany, where it is relatively certain that marine resources contributed to the diet (Schulting, Richards 2001). Because of their age, it is possible for the outliers to have had access to millet, a widespread $\mathrm{C}_{4}$ plant since the Late Bronze and Iron Ages. Without comparison with faunal samples, which are also absent from Téviec, it is difficult to discuss the nature of the isotopes for the outliers in any absolute sense. A tentative suggestion is that the observed trend may reflect a combination of both marine and millet intake.

The results of this study indicate that there are no correlations between the isotopic values of the Varna burials and their associated material wealth or inferred social stature. Although this does not refute the possibility of the wealth and social stature of these individuals, it suggests long-term dietary trends and that the differential access to food resources had no strong connection with such positions, if they existed. Nonetheless, all of the individuals burials in "the core" (Area E) at Varna shared similar isotopic values and therefore similar types of dietary protein, even if these values were not so very different from other areas of the cemetery. The enriched isotopic values of two Varna I burials - V43 and V51, with slight variations from other Varna I values - showed no significant difference from the full range of Durankulak Late Copper Age burials.

Diet is a central feature of prehistoric communities and the terrestrial diet of both mortuary populations despite their proximity to the Black Sea is a puzzling feature of these Neolithic and Copper Age societies. The minimal differentiation of individuals with more and higher-status grave goods from those with fewer and lower-status grave goods suggests that the diet of the living, in places perhaps some distance from the cemetery in the case of Varna but not so in the case of Durankulak, did not necessarily translate into mortuary gradations, which showed a greater reliance on material culture. The lack of correlation between grave location and isotopic dietary values at Varna suggests that varied groups of persons were buried in different parts of the cemetery. Overall, the isotopic results pose important questions for the relationship between food, status and persons in the Neolithic and Copper Age of the West Pontic zone.

\section{Acknowledgements}

The authors would like to thank Ondřej Mlejnek for his interest in this article. The original research underpinning this article formed part of Noah Honch's University of Oxford M.Sc. dissertation. John Chapman and Bisserka Gaydarska acknowledge the financial support of the British Academy for travel funding; John Chapman thanks the Bulgarian Academy of Science for travel and subsistence within Bulgaria; Tom Higham thanks the University of Oxford for his travel and subsistence costs; and Noah Honch acknowledges Lincoln College, Oxford, for his travel and subsistence costs. We are also grateful to Todor Dimov for providing us access to the animal bones curated at the Historical Museum of Dobritch, to Sonia Dimitrova for helpful assistance in Dobritch, to Nikolai Spassov for access to the National Museum of Natural History's faunal collection from Durankulak and to Kalin Dimitrov for drilling the Durankulak animal bones. Finally, Yavor Boyadzhiev was kind enough to discuss issues 
of Bulgarian Aeneolithic chronology and ${ }^{14} \mathrm{C}$ dating with us at the Varna Round Table (May 2004) and on subsequent occasions.

\section{References}

AKSU, A. E., HISCOTT, R. N., YAŞAR, D., IȘLER, F. I., MARSH, S. 2002: Seismic stratigraphy of Late Quaternary deposits from the southwestern Black Sea shelf: evidence for non-catastrophic variations in sealevel during the last $\sim 10000$ yrs. Marine Geology 190, 61-94.

BAILEY, D. 2000: Balkan prehistory. Routledge, London.

BONSALL, C., LENNON, R., MCSWEENEY, K., STEWART, C., HARKNESS, D., BORONEANT, V., BARTOSIEWICZ, L., PAYTON, R., CHAPMAN, J. 1997: Mesolithic and Early Neolithic in the Iron Gates: A Palaeodietary Perspective. Journal of European Archaeology 5(1), 50-92.

BOYADZIEV, Y. 1995: Chronology of Prehistoric Cultures in Bulgaria. In: Bailey, D. W., Panayotov, I. (Eds.): Prehistoric Bulgaria. Prehistory Press, Madison, USA, 149-192.

BOYADZIEV, Y. 2004: Chalcolithic stone Architecture from Bulgaria. Archaeologica Bulgarica VIII/1, 1-12.

BOZHILOVA, E., TONKOV, S. 1985: Palaeoecological studies in Lake Durankulak. Ann. Univ. Sofia Fac. Biol. 2:76, 25-30.

BOŽILOVA, E., TONKOV, S. 1998: Towards the vegetation and settlement history of the southern Dobrudza coastal region, north-eastern Bulgaria: a pollen diagram from Lake Durankulak. Vegetation History and Archaeobotany 7, 141-148.

BOŽILOVA, E., TONKOV, S. 2002: Paleoecological evidence on the vegetation history and human occupation in the coastal area of Lake Durankulak, Northeastern Bulgaria. In: Todorova, H. (Ed.): Durankulak, Band II: Die Prähistorischen Gräberfelder von Durankulak. Deutsches Archäologisches Institut, Berlin, 309-312.

CANNON, A., SCHWARCZ, H. P., KNYF, M. 1999: Marine-based Subsistence Trends and the Stable Isotope Analysis of Dog Bones from Namu, British Columbia. Journal of Archaeological Science 26, 399-407.

CATUNA, C. n.d.: Fragmenting and hoarding the ancestors: an economy of enchainment in the Gumelnița-Karanovo VI culture. MS.

CHAPMAN, J. 1990: Social Inequality on Bulgarian Tells and the Varna Problem. In: Samson, R. (Ed.): The Social Archaeology of Houses. Edinburgh University Press, Edinburgh.

CHAPMAN, J. 1991: The Creation of Social Arenas in the Neolithic and Copper Age of S.E. Europe: The Case of Varna. In: Garwood, P., Jennings, D., Skeates, R., Toms, J. (Eds.): Sacred and Profane: Proceedings of a Conference on Archaeology, Ritual, and Religion. Oxford University Press, Oxford, 152-171.

CHAPMAN, J. 2000: Fragmentation in Archaeology: People, Places and Broken Objects in the Prehistory of South Eastern Europe. Routledge, London.

CHAPMAN, J. 2004: Spondylus bracelets - fragmentation and enchainment in the East Balkan Neolithic and Copper Age. In: Slavchev, V. (Ed.) Festschrift für Prof. Dr. Habil. Henrieta Todorova. Dobrudzha 21, 63-87.

CHAPMAN, J. 2010: Houses, households, villages and proto-cities in Southeastern Europe. In: Anthony, D.W., Chi, J. Y. (Eds.): The lost world of Old Europe. The Danube Valley, 5000-3500 BC. Institute for the Study of the Ancient World, New York, 74-89.

CHAPMAN, J. 2012: From the Varna cemetery to the Tripolye mega-sites: new arenas of power. In Kienlin, T. L., Zimmermann, A. (Eds.): Beyond elites. Alternatives to hierarchical systems in modeling social formations. Rudolf Habelt, Bonn, 225-242.

CHAPMAN, J., HIGHAM, T., SLAVCHEV, V., GAYDARSKA, B., $\mathrm{HONCH}, \mathrm{N}$. 2006: The social context of the emergence, development and abandonment of the Varna cemetery, Bulgaria. European Journal of Archaeology 9/2-3, 159-183.

CHISHOLM, B. S., NELSON, D. E., SCHWARCZ, H. P. 1982: StableCarbon Isotope Ratios as a Measure of Marine Versus Terrestrial Protein in Ancient Diets. Science 216, 1131-1132.

COOK, G. T., BONSALL, C., HEDGES, R. E. M., MCSWEENEY, K., BORONEANT, V., PETTITT, P. B. 2001: A Freshwater Diet-Derived
${ }^{14} \mathrm{C}$ Reservoir Effect at the Stone Age Sites in the Iron Gates Gorge. Radiocarbon 43, 453-460.

DENIRO, M. J. 1985: Postmortem preservation and alteration of in vivo bone collagen isotope ratios in relation to palaeodietary reconstruction. Nature 317, 806-809

DENIRO, M. J., EPSTEIN, P. 1978: Carbon isotopic evidence for different feeding patterns in two hyrax species occupying the same habitat. Science 201, 906-909.

DENIRO, M. J., EPSTEIN, P. 1981: Influence of diet on the distribution of nitrogen isotopes in animals. Geochimica et Cosmochimica Acta 45: 341-351.

ELUÈRE, C. 1989: L'or de Varna. In: Le premier or de l'humanité. Musées Nationaux, Paris, 61-71.

GALE, N., STOS-GALE, Z., RADUNTCHEVA, A., IVANOV, P., LILOV, P., TODOROV, T., PANAYOTOV, I. 2000: Early metallurgy in Bulgaria. Godishnik NBU IV/V, 102-168.

GUMERMAN, G. 1997: Food and Complex Societies. Journal of Archaeological Method and Theory 4(2), 105-139.

HARE, P. E., FOGEL, M. L., STAFFORD, T. W., MITCHELL, A. D., HOERING, T. C. 1991: The isotopic composition of carbon and nitrogen in individual amino acids isolated from modern and fossil proteins. Journal of Archaeological Science 18, 277-292.

HEDGES, R. E. M., THOMPSON, J. M. A., HULL, B. D. 2005: Stable isotope variation in wool as a means to establish Turkish carpet provenance. Rapid Communication in Mass Spectrometry 19:22, 3187-3191.

HIGHAM, T., CHAPMAN, J., SLAVCHEV, V., GAYDARSKA, B., HONCH, N., BRONK RAMSEY, C., YORDANOV, Y., DIMITROVA, B. 2007: New AMS Radiocarbon Dates for the Varna Aeneolithic Cemetery, Bulgarian Black Sea Coast, Antiquity 81, 640-654.

HONCH, N. V., HIGHAM, T. F. G., CHAPMAN, J., GAYDARSKA, B., HEDGES, R. E. M. 2006: A palaeodietary investigation of carbon $(14 \mathrm{C} / 14 \mathrm{C})$ and nitrogen $(14 \mathrm{C} / 14 \mathrm{C})$ in human and animal bones from the Copper Age necropoleis of Varna and Durankulak, Bulgaria. Journal of Archaeological Science 33 (11), 1493-1504.

HOWLAND, M. R., CORR, L. T., YOUNG, M. M., JONES, V., JIM, S., VAN DER MERWE, N. J., MITCHELL, A. D., EVERSHED, R. P. 2003: Expression of the dietary isotope signal in the compound-specific $\delta^{13} \mathrm{C}$ values of pig bone lipids and amino acids. International Journal of Osteoarchaeology, 13 (1-2), 54-65.

IACUMIN, P., NIKOLAEV, V., GENONI, L., RAMIGNI, M., RYSKOVK YA. G., LONGINELLI, A. 2004: Stable isotope analyses of mammal skeletal remains of Holocene age from European Russia: A way to trace dietary and environmental changes. Geobios 37, 37-47.

IVANOV, I. 1975: Razkopki na Varnenskiya eneoliten nekropol prez 1972 g. Izvestia na Narodniya Muzeji Varna 11, 1-16.

IVANOV, I. 1988: Die Ausgrabungen des Gräberfeldes von Varna. In: Fol, A., Lichardus, J. (Eds.): Macht, Herrschaft und Gold. Moderne-Galerie des Saarlands-Museum, Saarbrücken, 49-66.

IVANOV, I. 2000: Varna and the Birth of the European Civilization. In: Varna Necropolis: The Dawn of European Civilization. SAGATÓ Publishers, Sofia.

JIM, S., JONES, V., AMBROSE, S., EVERSHED, R. P. 2006: Quantifying Dietary Macronutrient Sources of Carbon for Bone Collagen Biosynthesis Using Natural Abundance Stable Carbon Isotope Analysis. British Journal of Nutrition 95, 1055-1062.

KATZENBERG, M.A., WEBER, A. 1999: Stable Isotope Ecology and Palaeodiet in the Lake Baikal Region of Siberia. Journal of Archaeological Science 26, 651-659.

KIENLIN, T. 2012: Beyond elites: an introduction. In Kienlin, T. L., Zimmermann, A. (Eds.): Beyond elites. Alternatives to hierarchical systems in modelling social formations. Habelt, Bonn, 15-32.

KOSTOV, R. 2004: Gemologichna harakteristika na karneolovi i ahatovi munista ot halkolitnite nekropoli pri Durankulak i Varna. Geologija $i$ mineralni resursi 2004/10, 15-24.

KOSTOV, R., BAKUMSKA, A. 2004: Nefritovi artefakti ot rannoneolitnoto selishte Galabnik, Pernishko. Geologija i mineralni resursi 2004/4, 38-47.

LILLIE, M.C., RICHARDS, M. P. 2000: Stable Isotope Analysis and Dental Evidence of Diet at the Mesolithic-Neolithic Transition in Ukraine. Journal of Archaeological Science 27, 965-972.

LUBELL, D., JACKES, M., SCHWARCZ, H., KNYF, M., MEIKLEJOHN, C. 1994: The Mesolithic-Neolithic Transition in Portugal: Isotopic and 
Dental Evidence of Diet. Journal of Archaeological Science 21 (2), $201-216$.

MANHART, H. 1998: Die vorgeschichtliche Tierwelt von Koprivets und Durankulak und anderen prähistorichen Fundplätzen in Bulgarien aufgrund von Knochenfunden aus archäologischen Ausgrabungen. Documenta Naturae 116, 1-353.

MARINOVA, E. 2003: The new pollen core Lake Durankulak-3: a contribution to the vegetation history and human impact in Northeastern Bulgaria. In: Tonkov, S. (Ed.): Aspects of Palynology and Palaeoecology: Festschrift in honor of Elissaveta Bozilova. Pensoft Publishers, Sofia, 279-288.

MCCUllaGH, J. S. O., GAYE-SIESSEGGER, J., FOCKEN, U. 2008: Determination of underivatized amino acid $\delta^{13} \mathrm{C}$ by liquid chromatography/isotope ratio mass spectrometry for nutritional studies: the effect of dietary non-essential amino acid profile on the isotopic signature of individual amino acids in fish. Rapid Communications in Mass Spectrometry 22, 1817-1822.

PARKER PEARSON, M. 1999: The archaeology of death and burial. Alan Sutton, Stroud.

PÉTREQUIN, P., CASSEN, S., ERRERA, M., TSONEV, T., DIMITROV, L., MITKOVA, R. 2012. Les haches en roche alpines en Bulgarie. In Pétrequin, P.,Cassen, S., Errera, M., Classen, L., Sheridan, A. (Eds.): Jade. Grandes haches alpines du Néolithique européen. $V^{E}$ et IV millénaires av. J.-C. Cahiers de la MSHE C. N. Ledoux. Presses universitaires de Franche-Comté, Besançon.

POPOVA, T. 1995: Plant remains from Bulgarian prehistory (7000-2000 BC) In: Bailey, D. W., Panayotov, I. (Eds.): Prehistoric Bulgaria. Prehistory Press, Madison, USA, 193-208.

PRIVAT, K. 2004: Palaeoeconomy of the Eurasian Steppe: Biomolecular Studies. MS. D. Phil. Thesis. Deposited at University of Oxford.

RADUNTCHEVA, A. 1989. La société dans les Balkans à l'âge du cuivre. Dossiers Histoire et Archéologie 137, 46-55.

REIMER, P. J., REIMER, R. W. 2001: A marine reservoir correction database and on-line interface. Radiocarbon 43, 461-3.

RENFREW, C. 1978: Varna and the social context of early metallurgy. Antiquity 52, 199-203.

RENFREW, C. 1986: Varna and the emergence of wealth in prehistoric Europe. In: Appadurai, A. (Ed.): The Social Life of Things: Commodities in Cultural Perspective. Cambridge University Press, Cambridge.

RENFREW, C. 2000: Introduction. In: Varna Necropolis: The Dawn of European Civilization. AGATÓ Publishers, Sofia.

RICHARDS, M. P., HEDGES, R. E. M. 1999: Stable Isotopic Evidence for Similarities in the Types of Marine Foods Used by Late Mesolithic Humans at Sites Along the Atlantic Coast of Europe. Journal of Archaeological Science 26, 717-722.

SANDARS, N. K. 1985: Prehistoric Art in Europe (2 ${ }^{\text {nd }}$ ed.). Yale University Press, London.

SCHOENINGEN, M. J., DENIRO, M. J. 1984: Nitrogen and carbon isotopic composition of bone collagen from marine and terrestrial animals. Geochimica et Cosmochimica Acta 48, 625-639.

SCHULTING, R. J., RICHARDS, M. P. 2001: Dating Women and Becoming Farmers: New Palaeodietary and AMS Dating Evidence from the Breton Mesolithic Cemeteries of Téviec and Hoëdic. Journal of Anthropological Archaeology 20, 314-344.

SCHWARCZ, H. P., SCHOENINGEN, M. J. 1991: Stable Isotope Analyses in Human Nutritional Ecology. Yearbook of Physical Anthropology 34: 283-321.

SLAVCHEV, V. 2010: The Varna Eneolithic cemetery in the context of the Late Copper Age in the East Balkans. In: Anthony, D. W., Chi, J. Y.
(Eds.): The lost world of Old Europe. The Danube Valley, 5000 - 3500 $B C$. Institute for the Study of the Ancient World, New York, 192-210.

SPASSOV, N., ILIEV, N. 2002: The animal bones from the prehistoric necropolis near Durankulak (NE Bulgaria) and the latest record of Equus hydruntinus Regalia. In: Todorova, H. (Ed.): Durankulak Band II. Die prähistorischen Gräberfelder. Teil I. DAI, Berlin - Sofia - Anubis, 313-324.

TAUBER H. 1981: ${ }^{13} \mathrm{C}$ evidence for dietary habits of prehistoric man in Denmark. Nature 292, 332-333.

TODOROVA, H. 1983: Ausgrabungen in Durankulak, Bezirk Tolbuchin (Bulgarien), in der Periode 1975 - 1981. Nachrichten aus Niedersachsens Urgeschichte 52, $77-89$.

TODOROVA, H. 1986: Die Varna-Kultur an der westlichen Schwarzmeerküste. In: Internationales Symposium über die LengyelKultur in Nové Vozokany. Archäologisches Institut der Slowakischen Akademie der Wissenschaft in Nitra, Institut für Ur- und Frühgeschichte der Universität Wien, Nitra-Wien, 282-288.

TODOROVA, H. (Ed.) 1989: Durankulak (vol. 1). Bulgarian Academy of Science, Sofia.

TODOROVA, H. 1995: The Neolithic, Eneolithic, and Transitional Period in Bulgarian Prehistory. In: Bailey, D. W., Panayotov, I. (Eds.): Prehistoric Bulgaria. Prehistory Press, Madison, USA, 79-98.

TODOROVA, H. (Ed.) 2002: Durankulak, Band II: Die Prähistorischen Gräberfelder von Durankulak (2 vols). Deutsches Archäologisches Institut, Berlin.

TODOROVA, H. 2002a: Chronologie, horizontale Stratigraphie und Befunde. In: Todorova, H. (Ed.): Durankulak Band II. Die prähistorischen Gräberfelder. Teil I. DAI, Berlin - Sofia - Anubis, 35-52.

TODOROVA, H. 2002b: Die archäologische Geschlectsbestimmung. In: Todorova, H. (Ed.): Durankulak Band II. Die prähistorischen Gräberfelder. Teil I. DAI, Berlin - Sofia - Anubis, 53-60.

TODOROVA, H., DIMOV, T. 1989: Ausgrabungen in Durankulak 1974-1987. Varia Archaeologica Hungarica II, 291 - 306.

TODOROVA H., DIMOV, T., BOJADŽIEV, J., VAJSOV, I., DIMITROV, K., AVRAMOVA, M. 2002: Katalog der prähistorischen Gräber von Durankulak. In: Todorova, H. (Ed.): Durankulak Band II. Die prähistorischen Gräberfelder. Teil II. DAI, Berlin - Sofia - Anubis, 31-87.

VAN KLINKEN, G. J. 1999: Bone Collagen Quality Indicators for Palaeodietary and Radiocarbon Measurements. Journal of Archaeological Science 26, 687-695.

VAN KLINKEN, G. J., RICHARDS, M. P., HEDGES, R. E. M. 2000: An Overview of Causes for Stable Isotopic Variations in Past European Human Populations: Environmental, Ecophysiological, and Cultural Effects. In: Ambrose, S. H., Katzenberg, A. (Eds.): Biogeochemical Approaches to Palaeodietary Analysis. Kluwer Academic/Plenum Publishers, New York, 39-63.

VAN KLINKEN, G. J., VAN DER PLICHT, G. J., HEDGES, R. E. M. 1994: Bone C-13/C-12 ratios reflect (Palaeo-) climatic variations. Geophysical Research Letters 21, 445-448.

WHITTLE, A. 1996. Neolithic Europe. The creation of new worlds. Cambridge University Press, Cambridge.

YORDANOV, Y., DIMITROVA, B. 2002: Results of an anthropological study of human skeletal remains of the prehistoric necropolis in the vicinity of the village of Durankulak. In: Todorova, H. (Ed.): Durankulak Band II. Die prähistorischen Gräberfelder. Teil I. DAI, Berlin - Sofia Anubis, 325-347. 